IZA DP No. 534

\title{
The Insider-Outsider Theory: A Survey
}

Assar Lindbeck
Dennis Snower

J uly 2002 


\title{
The Insider-Outsider Theory: A Survey
}

\author{
Assar Lindbeck \\ IIES, Stockholm University and IUI, Stockholm \\ Dennis Snower \\ Birkbeck College, University of London, \\ CEPR and IZA Bonn
}

\section{Discussion Paper No. 534 \\ July 2002}

\author{
IZA \\ P.O. Box 7240 \\ D-53072 Bonn \\ Germany \\ Tel.: +49-228-3894-0 \\ Fax: +49-228-3894-210 \\ Email: iza@iza.org
}

This Discussion Paper is issued within the framework of IZA's research area Welfare State and Labor Market. Any opinions expressed here are those of the author(s) and not those of the institute. Research disseminated by IZA may include views on policy, but the institute itself takes no institutional policy positions.

The Institute for the Study of Labor (IZA) in Bonn is a local and virtual international research center and a place of communication between science, politics and business. IZA is an independent, nonprofit limited liability company (Gesellschaft mit beschränkter Haftung) supported by the Deutsche Post AG. The center is associated with the University of Bonn and offers a stimulating research environment through its research networks, research support, and visitors and doctoral programs. IZA engages in (i) original and internationally competitive research in all fields of labor economics, (ii) development of policy concepts, and (iii) dissemination of research results and concepts to the interested public. The current research program deals with (1) mobility and flexibility of labor, (2) internationalization of labor markets, (3) welfare state and labor market, (4) labor markets in transition countries, (5) the future of labor, (6) evaluation of labor market policies and projects and (7) general labor economics.

IZA Discussion Papers often represent preliminary work and are circulated to encourage discussion. Citation of such a paper should account for its provisional character. A revised version may be available on the IZA website (www.iza.org) or directly from the author. 
IZA Discussion Paper No. 534

July 2002

\title{
ABSTRACT \\ The Insider-Outsider Theory: A Survey*
}

This article is an idiosyncratic survey of the insider-outsider theory, describing the vision underlying the theory, and evaluating salient contributions to the literature in the light of this vision. We also indicate what appear to have been dead-ends and red herrings in past research. The first section deals with the theory, concerning how labor turnover costs influence insider wages and outsiders' opportunities and how these costs affect employment and unemployment. We also address the more complex, and open, question of how employment and unemployment move through time, in response to labor market shocks. The second section deals with the insider-outsider theory in relation to two important economic institutions: unions and social norms. The third section confronts the relevant empirical evidence. Finally, the last section concludes by clarifying some common misunderstandings and identifying promising areas of future research.

JEL Classification: J23, J24, J31, J32, J38, J41, J42, J51, J63, J64, J68

Keywords: employment, unemployment, wages, insiders, outsiders, unemployment persistence, social exclusion, labor turnover costs

\author{
Dennis Snower \\ Department of Economics \\ Birkbeck College \\ University of London \\ 7 Gresse Street \\ London W1P 1LL \\ UK \\ Tel.: +44 (207) 6316408 \\ Fax: +44 (207) 6316416 \\ Email: dsnower@economics.bbk.ac.uk
}

\footnotetext{
* We are deeply indebted to Will Baumol, James Malcomson, Andrew Oswald, and Ron Smith for profound comments.
} 


\section{Introduction}

The insider-outsider theory is concerned with the conflict of interest between insiders and outsiders in the labor market. "Insiders" are incumbent employees whose positions are protected by labor turnover costs. "Outsiders" enjoy no such protection; they could be unemployed or working in the informal, competitive sectors of the labor market. The theory examines how various types of labor turnover costs give insiders their market power, how they use this power to their own advantage (e.g., in pushing up their wages), how the insiders' activities affect the outsiders and vice versa, and what this insider-outsider interaction implies for employment, unemployment, and other macroeconomic activities.

The insider-outsider theory addresses some basic questions in labor economics and macroeconomics. For instance, what are the sources of unemployment? Why are labor markets segmented into "good jobs" (with relatively high wages and high job security) and "bad jobs"? What gives unions their clout? Why do wages depend not only on labor market conditions, but also on conditions inside the firms paying these wages? Why are inflation and real wages more closely related to short-term than to long-term unemployment? Why are the wages of workers in different occupational, educational, and seniority groups higher in some firms and sectors than in others?

The theory has also often been applied to the recent employment and unemployment experiences in developed countries, not only by academic economists, but also by national and international organizations. ${ }^{1}$ In particular, the theory has been used to address questions like these: Why has unemployment climbed in Europe over the past 25 years, while no trend seems to exist for the US in this period? Why have real wages risen sharply in Europe since the mid-1970s, despite high and rising unemployment? Why are employment and unemployment more persistent and less variable in most European countries than in the US? Why are productivity movements more pro-cyclical in most European countries than the in the US?

The starting point of the insider-outsider theory is the observation that labor turnover costs - costs associated with dismissal of incumbent employees and with

\footnotetext{
${ }^{1}$ Recent examples of the latter are the OECD (e.g. Elmeskov, et al. (1999)) and the IMF (e.g. World Economic Outlook, May 1999).
} 
hiring and training of new recruits - are prevalent in most market economies. The labor turnover costs, as discussed below, can take on a wide variety of forms, including costs arising from insiders' attempts to resist wage competition from outsiders by refusing to cooperate with them or harassing them. The theory then proceeds to show that these costs are borne, at least in part, by the employers and thus these costs give incumbent workers market power in the labor market. ${ }^{2}$ Schematically speaking, these labor turnover costs (LTCs) divide workers into three groups: (i) insiders, whose positions are protected by these LTCs, (ii) outsiders, who have no imminent prospect of such protection (e.g., the unemployed, workers in the informal sectors, and inactive individuals), and (iii) entrants, who hold jobs that may lead to insider status.

When an outsider is hired, he becomes an entrant. Once an entrant has remained with the firm for a span of time (the "initiation period") sufficiently long to become associated with the same labor turnover costs as the insiders, the entrant has an opportunity to renegotiate the wage. In effect, the entrant thereby turns into an insider. Periodic renegotiation of wages arises partly for legal reasons (employment law usually allows for renegotiation of contracts, usually by mutual consent and sometimes at the initiative of just one party ${ }^{3}$ ). Another reason is that it is usually impossible in practice to write contracts contingent on all the possible future events that may be relevant to the employment relationship.

In practice, the difference between insiders and outsiders is a matter of degree rather than of kind. As people's duration of employment rises, the labor turnover costs associated with their positions often rise as well. Consequently, the greater their seniority, the more protected their positions become. Similarly, as people's duration of unemployment rises, their connections with their previous colleagues and employers often fade and the more difficult it becomes for them to compete for the available jobs. Thus there are many degrees of being an insider and outsider. In economic model building, a distinction between homogeneous groups of "insiders" and "outsiders" is made only for expositional and analytical simplicity.

The distinction between insiders and outsiders can be made along a variety of divides: employed versus unemployed workers, people with "good jobs" versus "bad

\footnotetext{
${ }^{2}$ For an early development of this point, see Lindbeck and Snower $(1984,1986)$.
} 
jobs" (viz., formal versus informal sector jobs), employees with high versus low seniority, unionized versus non-unionized workers, employees who have significant firm-specific skills and those who do not, workers on permanent contacts and those on temporary (fixed-term) ones, those who have a voice in the wage bargaining process and those who do not, the short-term unemployed versus the long-term unemployed, those entitled to state benefits and those who are not, and so on.

These distinctions also translate into social differences. In many developed countries nowadays growing attention is devoted to the phenomenon of "social exclusion." Some individuals, families and other social groups are excluded from the mainstream networks of social relations within a society. They are typically unemployed or working at temporary, low-grade, or dead-end jobs, and finance much of their consumption out of transfer payments. Some become long-term clients of various social assistance programs; others live on their parents' incomes, the black market, or even criminal activities. They often live in the underclass neighborhoods of large cities, with meager social services, poor schooling, and scant police protection. These are the real "outsiders" in society, and their outsider position in the labor market is an important source of their social exclusion.

The LTCs, underlying these dichotomies, may be divided into two categories: "production-related" costs, which must be expended in order to make outsiders productive within a firm, and "rent-related" costs, which are the outcome of insiders' rent-seeking activities. Whereas the production-related costs may be considered part of the production process, the rent-related costs result from wasteful redistributive battles between insiders and outsiders (analogous to the redistributive battles in the public choice literature). ${ }^{4}$ The latter costs are aimed at making the insiders' positions more secure and raising their wages, often by discouraging firms from hiring outsiders.

The LTCs are a type of transactions cost, in the sense of Coase (1937) and Williamson (1975). They give insiders some clout over their employers. The insiders are able to influence the terms of their employment conditions in their own favor possibly at the expense not only of outsiders but also the employers - without

\footnotetext{
${ }^{3}$ See, for example, Malcomson (1997) for details.

${ }^{4}$ For example, Tullock (1967). Hillman and Ursprung (1999) distinguishes between insiders and outsiders on the basis of political power.
} 
inducing their employers to replace them with new entrants. In particular, the insiders can drive their wages above the minimum levels necessary to retain and motivate them at their current jobs (in contrast to the efficiency wage theory, where firms set wages at these minimum levels). They can also push for seniority rules, whereby firing takes place on a 'last in, first out" basis. And they can drive the entrants' wages above the minimum levels necessary to attract them. The insiders are able to do all this since the turnover costs discourage their employers from dismissing them. In short, labor turnover costs give the insiders market power, which they use to their own advantage. Identifying labor turnover costs as the source of insider power has an important payoff, generating a wide range of empirical testable hypotheses and policy implications, as shown below.

Wages and other terms of employment are the outcome - implicitly or explicitly - of a bargaining process between insiders and their employers. The outsiders are usually disenfranchised from this process. The outsiders are then simply not party to the negotiations that set the insiders' conditions of employment and, often, not even party to the process that determines the entrants' conditions. In this way, outsiders wind up with less favorable labor market opportunities than the insiders. But although the outsiders' circumstances don't influence these negotiations directly, they may nevertheless do so indirectly, say, through their influence on the employers' search costs or on the insiders' outside options (e.g., the insiders' reemployment probabilities if they are fired).

As discussed below, a profound consequence of the outsiders' less favorable conditions of employment is that the outsiders may be involuntarily unemployed or involuntarily confined to "bad jobs" (jobs with relatively low wages and/or low expected tenure). Specifically, some outsiders may be unable to work their way into insiders' jobs even though they are willing to work for less than the insider wages, normalized for productivity differences and other production-related turnover costs. In this sense, outsiders face discrimination in the labor market: vis-a-vis the insiders, they do not receive equal reward for equal productivity. This discrimination, arising through the insiders' exploitation of the rent-related turnover costs, exists because outsiders have less favorable choice sets than insiders, either at any given point in 
time, or over their lifetimes. In either case, the outsiders' unemployment, or secondary-sector employment, is "involuntary" and wasteful. ${ }^{5}$

The insider-outsider theory is of course not the only theory concerned with these phenomena. Broadly speaking, if we classify theories in terms of the fundamental incentives faced by participants in the labor market, there are three main ways of explaining why some workers face less favorable employment conditions than others do. These correspond to the three general reasons why firms may be unwilling to replace their insiders by outsiders, even though the outsiders are willing to work for less than the insiders, after allowing for the production-related turnover costs:

(i) Politicians, civil servants and lobby groups have incentives to regulate wages above their market-clearing levels - through minimum wage laws or legislated coverage of union wage agreements over non-unionized workers - making it illegal for firms to accept the outsiders' underbidding.

(ii) Firms may not accept the outsiders' underbidding, since a fall in the wage may reduce the average productivity of their workforces. Alternatively, a fall in the wage may raise the quit rate and thereby raise the firm's total cost of labor turnover. This is the approach of the efficiency wage theory. ${ }^{6}$

(iii) And finally, according to the insider-outsider theory, it may not be in the insiders' interests to allow the outsiders to underbid, and the insiders - acting individually or collusively (e.g., in unions) - may be able to impose their interests on their employers, since the insiders' positions are protected by LTCs. ${ }^{7}$ The labor union and wage bargaining literature also falls into this area, since the insider-outsider theory provides a rationale for unions and identifies

\footnotetext{
${ }^{5}$ By the same token, when the long-term unemployed are unable to compete on an equal basis with the short-term unemployed, since the latter have better connections with employers and employees, the long-term unemployed are involuntarily marginalized.

${ }^{6}$ While in some versions of the efficiency wage theory firms use wages as an incentive device to tackle problems of adverse selection (e.g. Weiss (1980)) or moral hazard (e.g. Shapiro and Stiglitz (1984)), other versions address considerations of fairness (e.g. Akerlof (1982)).

7 Note that both the insider-outsider theory and some variants of the efficiency wage theory are concerned with labor turnover costs, but in the latter firms offer higher wages in order to minimize workforce turnover (and hence production-related LTCs), whereas in the former insiders push for higher wages because their jobs are protected by production- and rent-related LTCs.
} 
the sources of wage bargaining power. (But, as explained below, the purview of the insider-outsider theory extends far beyond union activities.)

These three approaches to discrimination in the labor market - government regulation of wages, efficiency wages, and insider-outsider conflict - are often interrelated. ${ }^{8}$

This article is an idiosyncratic survey of the insider-outsider theory. It is idiosyncratic in that its overriding aim is not to provide a comprehensive summary of the relevant literature (which has been attempted by others ${ }^{9}$ ), but rather to describe the vision underlying the theory, and to evaluate salient contributions to the literature in the light of this vision. We will also indicate what appear to have been dead-ends and red herrings in past research. The rest of this article is divided into four sections. The first deals with the theory, concerning how labor turnover costs influence insider wages and outsiders' opportunities and how these costs affect employment and unemployment. We also address the more complex, and open, question of how employment and unemployment move through time, in response to labor market shocks. The second section deals with the insider-outsider theory in relation to two important economic institutions: unions and social norms. The third section confronts the relevant empirical evidence. Finally, the last section concludes by clarifying some common misunderstandings and identifying promising areas of future research.

\section{The Theory}

\section{Labor Turnover Costs and Insider Wage Formation}

The reason why labor turnover costs are the source of insiders' market power is that these costs fall significantly on firms and that the firms are generally unable to pass these costs on fully to their insiders. One explanation for this is that firms do not incur these costs until they replace their insiders with newly recruited entrants. Furthermore, whereas firms could, in principle, shift LTCs to their insiders through insider "exit fees" - lump sum payments by insiders to their employers upon voluntary quitting or firing "without cause" - such fees are usually illegal and incentive incompatible. Incentive incompatibility arises because it is often difficult to

\footnotetext{
${ }^{8}$ See, for example, Lindbeck and Snower (1991) and Sanfey (1993).
} 
assess whether a separation is generated by firing "with cause," firing "without cause," or voluntary quitting, and consequently exit fees would encourage firms to replace their insiders by entrants in order to obtain such fees.

Both production-related and rent-related LTCs are common in most labor markets. Hiring costs (such as firms' search and screening costs) are often productionrelated; firing costs (such as litigation against dismissal) are often rent-related. The LTCs - particularly the rent-related ones - come in many guises. For instance, the firing costs may take the form of severance pay, seniority rules, requirements that firms give insiders advance notice of dismissal, ${ }^{10}$ and other forms of legal protection against firing. Many of these costs are manipulable by insiders, enabling them to influence their own market power. For instance, insiders may use their political influence to raise such costs. ${ }^{11}$ In addition, insiders may be able to protect their jobs and keep their wages from being underbid by cooperating with one another in the production process (thereby raising each others' productivity), but refusing to cooperate with outsiders offering to work for less. The resulting insider-entrant productivity differential is a labor turnover cost that is also manipulable by the insiders. For the same reason, insiders may be on friendly terms with one another but "harass" underbidding new recruits, thereby generating an insider-entrant reservation wage differential that translates into a labor turnover cost. ${ }^{12}$ Labor turnover costs associated with cooperation and harassment activities are likely to be particularly significant whenever work is performed in teams.

The literature on imperfect information suggests some other types of labor turnover costs as well: (a) When insiders are promoted on the basis of past effort, a rise in the probability of being fired reduces the expected future reward for current effort and may induce workers to reduce that effort. The result is an effort-related labor turnover cost. ${ }^{13}$ (b) Suppose that a firm's stockholders and creditors have imperfect information about the firm's credit-worthiness, and the firm knows that its firing decisions are used as a signal of its risk of illiquidity. The result is another risk-

\footnotetext{
${ }^{9}$ For example, Ball (1990), Sanfey (1995).

${ }^{10}$ Shaked and Sutton (1984) were the first to explore how wage bargaining is influenced by the time span over which a firm is committed to bargain with its insiders.

${ }^{11}$ See, for example, Lindbeck and Snower (1988d, ch. 11) and Saint-Paul (1996).

12 See Lindbeck and Snower (1988a).

${ }^{13}$ See Lindbeck and Snower (1988b).
} 
related turnover cost that protects the insiders' positions. ${ }^{14}$ (c) Beyond that, in regions with tight labor markets, firms' cost of attracting new recruits from other geographic regions is another type of LTC. In particular, the resulting mobility costs - such as those of buying and selling houses - may be borne in part by firms, in the form of higher entrant wages (Oswald (1999)).

For these various reasons, it is erroneous - though common - to suppose that labor turnover costs are important only in labor markets characterized by stringent job security legislation and high union density, such as those in many European countries. Surveying the many forms that labor turnover costs can take, it becomes clear that these costs may be widespread and significant even in the absence of severance pay, unions, and other forms of legislated job protection. ${ }^{15}$ By implication, it is reasonable to believe that the insider-outsider theory is also applicable to the U.S.

To see why labor turnover costs are the ultimate source of insiders' market power, it is useful to recognize that a firm generally has two alternative partners in wage negotiations: the insiders and the outsiders. Labor turnover costs determine the degree of substitutability between these two alternative negotiations. The smaller are the firm's labor turnover costs (ceteris paribus), the more profitable it is for the firm to stop bargaining with its insiders and start bargaining with the outsiders instead. Thus the more the insider wage will depend on the wage the firm could have negotiated with the outsiders. When turnover costs are zero, the two sets of negotiations are perfect substitutes and the insider wage is driven down to the reservation wage of the marginal worker. When these costs are prohibitively high, the firm and its insiders have bilateral monopoly power. In between these two extremes, labor turnover costs affect not just the outside options and fallback positions of the bargaining partners, but the nature of the bargaining process itself. This bargaining problem, analyzed formally in Manzini and Snower (1998), shows that insiders' market power may be regarded as rising with labor turnover costs.

In effect, the LTCs may be interpreted as entry barriers, making it difficult for workers to enter the labor market. Just as product markets become perfectly

\footnotetext{
${ }^{14}$ We are indebted to Joe Stiglitz for bringing point (b) to our attention. Just as firing decisions are a negative signal (indicating that the firm may be in trouble), so hiring decisions may be a positive signal. This phenomenon discourages firing and stimulates hiring, in contrast to the other turnover costs that discourage both firing and hiring.

${ }^{15}$ For a summary of some empirical evidence, see Malcomson (1998, Table 1).
} 
contestable when there are no barriers to the entry and exit of firms, ${ }^{16}$ so labor markets are perfectly contestable when there are no LTCs. In that event, the threat of entry will keep the wage at the competitive level; i.e., the wage will be equal to the reservation wage of the marginal entrant. The reason is that if the insiders were to make wage claims above the competitive level, entrants could come into the labor market and underbid them and exit if the insiders retaliate. In the presence of labor turnover costs, however, the labor market is imperfectly contestable and thus insiders have the market power to earn more than the competitive wages, just as firms in imperfectly competitive product markets can charge more than the competitive prices.

Yet even within a one-period Nash bargaining context, it is easy to see how labor turnover costs generate insiders' market power. The following simple example makes this point transparently. Consider a firm bargaining individualistically with each of its employees. There are constant returns to labor, with each insider generating output $a^{I}$ (a positive constant) per period of analysis and earning a wage $w^{I}$. Under bargaining agreement, the firm's profit is $a^{I}-w^{I}$ and the insider's gain is $w^{I}$. Under disagreement, the insider engages in an obstructive activity (e.g., strike, picket, work-to-rule, and sabotage), costly to the firm. Let the firm's cost of firing the insider be $f$ (a positive constant), and the firm's profit from hiring an entrant be $\left(a^{E}-w^{E}-h\right)$, where $a^{E}$ is the output per entrant, $w^{E}$ is the entrant wage, and $h$ is the hiring cost. Assuming, for simplicity, that the insider's obstructive activity is costless to the insider, it follows that this activity will be high enough to reduce the firm's fall-back profit to the profit from replacing the insider by an entrant: $\pi^{o}=\left(a^{E}-w^{E}-h\right)-f$. Let the insider's fall-back payoff be $w^{o}=w^{E}$. In this simple setting, the total labor turnover cost (per worker) is $c=\left(a^{I}-a^{E}\right)+(h+f)$, i.e., the insider-entrant productivity differential plus the hiring and firing costs. Under these circumstances, it is easy to show that the negotiated insider wage is ${ }^{17}$

$$
w^{I}=\mu c+w^{E}
$$

\footnotetext{
${ }^{16}$ See Baumol, Panzar and Willig (1982).

${ }^{17}$ Under disagreement, the firm's fall-back profit is $\pi^{\mathrm{o}}$ and the insider's fall-back payoff is $w^{o}$. In this simple model, there are constant returns to labor and the insider wage is renegotiated in each period. Thus the insider's current wage does not affect his future wage or employment chances. Thus the negotiated insider wage is the solution of the following one-period Nash bargaining problem:
} 
where $\mu$ is the bargaining strength of the insider relative to the firm. ${ }^{18}$ Observe that in the absence of labor turnover costs $(c=0)$, the insider wage would be equal to the entrant wage $\left(w^{I}=w^{E}\right)$. In the presence of LTCs, as equation (1) indicates, these costs drive a wedge between the insider and entrant wages. The greater are the LTCs, the greater will be the wage differential.

It is worth noting that the insider wage depends on factors both "inside" and "outside" the firm. The turnover cost $c$ depends on "inside" factors, such as the productivity of insiders and entrants $\left(a^{I}\right.$ and $\left.a^{E}\right)$, whereas the entrant wage $w^{E}$ generally depends "outside" factors, namely, the outside options of entrants (which depend on the unemployment rate, unemployment benefits, the wages offered by other firms, and so on). The greater the hiring and firing costs ( $h$ and $f$ ), the more the insider wage will depend on the "inside factors" relative to the "outside factors."

Accordingly, when we allow for gradations of insiders, associated with LTCs rising with their job tenure, we obtain wage scales. The human capital theory ${ }^{19}$ predicts that the slope of intertemporal wage scales depends on how workers' productivities change with their length of job tenure, and the efficiency wage theory ${ }^{20}$ predicts that this slope is set by the firm so as to motivate their employees. By contrast, the insider-outsider theory predicts that this slope is determined by the way labor turnover costs depend on job tenure. Since labor turnover costs (as a function of job tenure) are generally not perfectly correlated with productivity and incentive effects (again as a function of tenure), this prediction of the insider-outsider theory is empirically distinguishable from the predictions of the human capital and efficiency wage theories.

In this context, the insider-outsider theory is also able to account for the observation that some firms pay their workers - regardless of the occupations, ages, and tenure groups from which they are drawn - higher wages than other firms do. The explanation is that these various groups of workers cooperate in the production process and thus, to some extent, their wages reflect their pooled hbor turnover costs.

\footnotetext{
$\arg \max _{I}\left(w^{I}-w^{o}\right)^{\mu}\left(a^{I}-w^{I}-\pi^{o}\right)^{1-\mu}=\mu\left(a^{I}-\pi^{o}\right)+(1-\mu) w^{o}$. Letting $\pi^{o}=\left(a^{E}-w^{E}-h\right)-f$ and $w^{o}=w^{E}$, we obtain equation (1).

${ }^{18}$ When $\mu=1$, the insider captures all the available economic rent; and when $\mu=0$, the firm does so.

${ }^{19}$ For example, Becker (1962).

${ }^{20}$ For example, Lazear (1981).
} 
For instance, industries that pay comparatively high wages to their white-collar workers (on account of these workers' high turnover costs) may pay comparatively high wages also to their blue-collar workers (even if these workers are ot associated with high turnover costs). One reason is that the white- and blue-collar workers may be complementary in the production process, and thus the latter group may gain market power from the former. Another reason is that, in the presence of industrial bargaining, the two groups may explicitly pool their market power, based on their joint labor turnover costs.

Numerous studies have also found that industries that pay comparatively high wages tend to have relatively high profits, high concentration ratios in product markets, high capital-labor ratios, and high union density. ${ }^{21}$ The insider-outsider theory explains these stylized facts by indicating, as noted, that insiders' wages are the outcome of a process whereby insiders and their employers share the available economic rent. Thus insider wages will be higher, the more their employers stand to lose from a breakdown in wage negotiations. Lindbeck and Snower (1990a) show that, under a broad range of conditions, firms stand to lose more, the greater (a) the profit opportunities available under agreement, (b) the capital-labor ratio, and (c) the concentration ratio. Moreover, the greater is union density in an industry, the more leverage unions are able to give insiders in their threats of obstructive activity under bargaining disagreement, and thus the greater is the bargaining surplus and the higher the resulting insider wages.

\section{The Influence of Insider Power on the Outsiders' Opportunities}

When insiders use their market power to improve their labor market opportunities, what happens to the opportunities of the outsiders and how do entrant wages respond?

If the entrants had no market power and there were no lower bounds to their pay, the marginal entrants would always receive their reservation wage $r$, which makes them indifferent between working and staying jobless over their remaining lifetime. Then a rise in the insider wage would be balanced by an equal fall in the entrant wage (in present value terms). In a two-period framework - with a discount

\footnotetext{
${ }^{21}$ See, for example, Dickens and Katz (1986).
} 
factor $\delta$ and the present value of utility from leisure (over the two periods) $v$ - the relation between the insider wage $w^{I}$ and the entrant wage $w^{E}=r$ then is ${ }^{22} w^{I}=v-\delta r$. Under these circumstances, the insiders' exercise of market power on their wages would have no influence on the present value of labor costs for new recruits $(r+$ $\left.(1 / \delta) w^{I}\right)$, and thus the firms employment decisions would be unaffected. ${ }^{23}$

Since insiders' wages are usually well above the amount necessary to keep them from dropping out of the labor force and since these wages are paid over much of their working lifetimes, the entrants' reservation wage is usually very low - in the main, substantially negative. In practice, however, we do not observe entrants paying large sums of money to purchase jobs from their employers. There are various reasons why this is so.

First, entrants may be unable to pay a large, negative reservation wage on account of credit constraints. Second, such a reservation wage may be infeasible on account of minimum wage laws, social norms, or union pressure on firms. Third, entrants may have some market power, since firms often expend costs in hiring them (e.g., advertising, screening, and on-the-job training costs). Indeed, if hiring costs are incurred before the firm negotiates the wage with the entrant (e.g., advertising, interviewing costs) then, by the time the wage negotiations occur, these costs are a bygone that will not affect the wage in standard bargaining theory. ${ }^{24}$

Fourth, firms may offer entrants more than their eservation wages to avoid the following incentive incompatibility problem. ${ }^{25}$ When entrants anticipate that they will become insiders - thus remaining "bonded" to the firm, expecting to receive the high insider wages in the future - let their reservation wage be $r_{B}$ (where " $r$ " stands for the reservation wage and $B$ stands for "bonding"). If $r_{B}$ is sufficiently low, entrants are more profitable than insiders are, thereby giving firms an incentive to "churn" (i.e., dismiss the entrants before they turn into insiders). Under churning, however, the entrants' reservation wage is higher, call it $r_{C}$ (where $C$ stands for "churning"), where $r_{C}>r_{B}$. Under these circumstances, firms may find it profitable to offer an entrant

\footnotetext{
22 Combining this relation with equation (1), we find that the equilibrium insider wage is $w^{I}=\frac{1}{1+\delta} v+\frac{\delta}{1+\delta} \mu c$.

${ }^{23}$ This point has been made by Bertola (1990) and others.

${ }^{24}$ We are grateful to James Malcomson for this point.
} 
wage $w_{E}$, where $r_{C}>w_{E}>r_{B}$, so as to lose the incentive to churn and thereby induce entrants to accept a wage beneath $r_{C}$.

And finally and crucially, insiders may use their market power to influence not only their own wages, but those of the entrants as well. In the union literature it is often assumed that insiders bargain over both sets of wages, but even when workers are not unionized they may nevertheless have an incentive to collude to influence entrant wages. At first sight, it may appear that when the insiders' positions are protected (by the LTCs and possibly also by seniority rules), both the insiders and their employers have an incentive to set the entrant wages as low as possible (equal to the entrants' reservation wages), for then the resulting economic rent (to be shared between the insiders and their employers) is maximized. ${ }^{26}$

But in an intertemporal context, this need not be so. ${ }^{27}$ The lower entrant wages are set (ceteris paribus), the greater the employment of entrants. ${ }^{28}$ If entrants turn into insiders in the future, the future insider workforce will expand. Thus, if insiders and entrants are substitutes in the production process, the current insiders will be worse off in the future, since their future wages or future retention probabilities will fall. On the other hand, if firms adopt a two-tier wage system - with the wages of the current entrants remaining permanently lower than the wages of the current insiders - then firms in the future may have an incentive to dismiss their high-wage senior employees and retain their low-wage junior employees. To avoid such adverse contingencies, the current insiders may push entrant wages above the entrants' reservation wage, thereby restricting the firms' employment of entrants.

Furthermore, when product markets are imperfectly competitive, insiders may also have an incentive to set the entrant wages above the reservation wage, thereby restricting employment. The reason is that thereby the insiders enable their firms to restrict output and raise the product price. The resulting increase in monopoly surplus can be split between the insiders and their firms. ${ }^{29}$

\footnotetext{
${ }^{25}$ See Manzini and Snower (1998).

${ }^{26}$ See Frank and Malcomson (1994) and Gollier (1991).

${ }^{27}$ See Begg (1988).

${ }^{28}$ We assume a "right to manage" model, in which wages are the outcome of negotiations between firms and their insiders, while employment decisions are made unilaterally by the firms.

${ }^{29}$ See Gollier (1991).
} 
Under these various circumstances, labor turnover costs raise the insider wages, but entrant wages do not fall by equivalent amounts (in present value terms). Thus entrant wages are raised above the reservation wage (at which entrants are indifferent between work and leisure over their lifetimes). In this way the LTCs raise the present value of firms' wage costs of the marginal worker, and lead firms to reduce employment. outsiders would prefer to find employment to remaining unemployed, but since firms have reduced their employment, the outsiders are unable to find jobs. The outsiders' choice sets are thus inferior to those of the insiders (at any point in time and over their lifetimes).

\section{How Labor Turnover Costs Affect Employment and Unemployment}

Labor turnover costs have two effects on employment, a direct effect and an indirect effect operating via wages. The direct effect is simple: Given wages, turnover costs discourage firms from hiring when labor demand rises and from firing when labor demand falls. The medium-run implications are straightforward. Employment inertia increases, so that firms' current employment depends more strongly on past employment. Thus, in the aftermath of recessions - such as those of the mid-1970s, early 1980s, and early 1990s - employment will tend to remain lower than it would otherwise have been. Many continental European firms, facing relatively high LTCs, have been particularly vulnerable to this phenomenon. Obversely, in the aftermath of booms, employment will tend to remain relatively high.

Other medium-run implications concern working hours and capital-labor substitution. Since labor turnover costs are usually associated with replacement of employees rather than variation in their hours of work, the greater are these costs, the greater will be the degree to which macroeconomic fluctuations lead to variations in working hours rather than variations in people employed. Furthermore, the greater are these costs, the greater will be firms' incentives to respond to cyclical fluctuations through capital-labor substitution rather than through hiring and firing. Consequently, the more pro-cyclical will the swings in productivity be. These various medium-run effects may extend over many years (often a decade or more into the future), and thus deserve at least as much attention as the long-run effects, to which we now turn. 
Over the long run, the influence of labor turnover costs on employment is less clear-cut. Let $N$ be the long-run aggregate employment level, given the capital stock and the available technologies. Let $\tau$ be a labor turnover cost (say, a hiring or firing cost), and let $w$ be the long-run wage. Then the influence of the labor turnover cost on long-run employment may be expressed as

$$
\frac{d N}{d \tau}=\frac{\partial N}{\partial \tau}+\frac{\partial N}{\partial w} \frac{\partial w}{\partial \tau}
$$

where the first right-hand term is the direct effect and the second is the indirect (wagemediated) effect. $^{30}$ Since the LTC discourages both hiring (in booms) and firing (in recessions), the direct effect of the LTC on long-run employment $(\partial N / \partial \tau)$ could be positive or negative, a well-known result. Its sign depends on the elasticities of hiring and firing with respect to the LTC. ${ }^{31}$

The literature in this area indicates that the direct effect on employment depends on such factors as the discount rate, the stochastic process generating the

\footnotetext{
${ }^{30}$ Vetter and Andersen (1994) derive the result that the exercise of insider power raises employment relative to the competitive outcome. To reach this conclusion, they not only assume that entrants receive their reservation wages (so that the indirect effect is zero), but also that (a) the labor turnover cost is production-related (a training cost), (b) it is not manipulable by the insiders, and (c) insiders can reduce their wages to avoid entrants' underbidding while under competitive conditions these same workers don't do this. In short, the unrealistic result is based on the unrealistic underlying assumptions. 31 On a macroeconomic level, the long-run direct effect of labor turnover costs on employment can be formulated quite simply as follows. Observe that the change in aggregate employment $\left(\Delta N_{t}\right)$ is equal to the number of people hired $\left(\eta U_{t-1}\right.$, if people are hired solely from the unemployment pool, where $\eta$ is the hiring rate and $U_{t-1}$ is last period's unemployment level) minus the number of people leaving employment $\left(\sigma N_{t-1}\right.$, where $\sigma$ is the separation rate and $N_{t-1}$ is last period's employment level): $\Delta N_{t}=$ $\eta U_{t-1}-\sigma N_{t-1}$. Unemployment $\left(U_{t-1}\right)$ is the difference between the labor force $\left(L_{t-1}\right)$ and employment $\left(N_{t-}\right.$ $\left.{ }_{1}\right), U_{t-1}=L_{t-1}-N_{t-1}$. If the labor force is constant (at $L$ ), the steady-state employment level is $N=$ $(\eta /(\eta+\sigma)) L$.
}

Now let $\varepsilon_{\tau}^{\eta}$ and $\varepsilon_{\tau}^{\sigma}$ be the elasticities of the hiring and separation rates (respectively) with respect to the LTC $\left(\varepsilon_{\tau}^{\eta}, \varepsilon_{\tau}^{\sigma}<0\right)$. Furthermore, let $\varepsilon_{f}^{w}$ be the elasticity of the wage with respect to the LTC $\left(\varepsilon_{\tau}^{w}>0\right)$. Finally, let $\varepsilon_{w}^{\eta}$ and $\varepsilon_{w}^{\sigma}$ be the elasticities of the hiring and separation rates (respectively) with respect to the wage $\left(\varepsilon_{w}^{\eta}<0, \varepsilon_{w}^{\sigma}>0\right)$. Assuming that the LTC has no effect on the labor force, the total (direct plus indirect) effect of the LTC on employment can be shown to be $\frac{d N}{d \tau}=\frac{\sigma \eta L}{\tau(\eta+\sigma)^{2}}\left(\varepsilon_{\tau}^{\eta}-\varepsilon_{\tau}^{\sigma}\right)+\frac{\sigma \eta L}{\tau(\eta+\sigma)^{2}} \varepsilon_{\tau}^{w}\left(\varepsilon_{w}^{\eta}-\varepsilon_{w}^{\sigma}\right)$ where the first right-hand term is the direct effect and the second is the indirect effect. Note that although the sign of the direct effect is ambiguous (since the sign of $\varepsilon_{f}^{\eta}-\varepsilon_{f}^{\sigma}$ is ambiguous), the sign of the indirect effect is unambigously negative: $\varepsilon_{f}^{w}\left(\varepsilon_{w}^{\eta}-\varepsilon_{w}^{\sigma}\right)<0$, since $\varepsilon_{f}^{w}>0, \varepsilon_{w}^{\eta}<0$ and $\varepsilon_{w}^{\sigma}>0$. If the firing elasticity exceeds the hiring elasticity 
demand shocks, the rate of productivity growth, and the quit rate. Bentolila and Bertola (1990) show that when the labor market shocks take the form of Brownian motion (i.e., permanent shocks), then firing costs stimulate average employment. The reason is that they discourage firing more than hiring, because when a firm fires, it incurs the firing costs immediately, but when it hires these costs lie in the uncertain future. $^{32}$ Conversely, hiring costs - not only screening and training costs, but also those associated with insiders' cooperation and harassment activities (discussed above) - reduce average employment, because when a firm hires, it incurs the hiring costs immediately, but when it fires these costs are uncertain and in the future.

Bentolila and Saint-Paul (1994) indicate that this result may be overturned when firms face idiosyncratic productivity shocks, since a rise in firing costs reduces the number of firms engaged in firing. Bertola (1992) shows that the above result is overturned when the marginal revenue product curve is sufficiently convex, so that the marginal revenue product in a boom is sufficiently low relative to its value in a slump. Chen, Snower, and Zoega (1999) show how that the expected employment effect of firing costs depends on the combination of productivity growth and the probability of recession or boom.

By contrast, the indirect effect of labor turnover costs on employment, $(\partial N / \partial w)(\partial w / \partial \tau)$, is generally not ambiguous and could well be large. As noted in the previous section, an increase in labor turnover costs may generally be expected to raise the present value of firms' wage costs. Thereby they reduce hiring and increase firing, thereby leading to a fall in employment.

Taking the direct and indirect effects together, it is worth noting that the influence of LTCs on employment and unemployment depends on the nature of macroeconomic fluctuations. Lindbeck and Snower (1988c, ch. 11) argue that when business cycles are short and shallow (as in the 1950s and 1960s), labor turnover costs encourage labor hoarding in recessions, and thus these costs may have only a small (and possibly positive) effect on employment. But when the cycles are long and deep (as in the aftermath of the two oil price shocks and the recession of the early 1990s),

in absolute value terms $\left(\left|\varepsilon_{\tau}^{\sigma}\right|>\left|\varepsilon_{\tau}^{\eta}\right|\right.$ ), then the direct effect is negative, and then the total (direct plus indirect) effect will be negative as well. 
the labor turnover costs may not do much to discourage layoffs in recessions, but they do discourage hiring in booms. Under these circumstances, LTCs may have a strong adverse influence on employment. ${ }^{33}$

Another channel whereby labor turnover costs may reduce employment is described by the hold-up problem. ${ }^{34}$ LTCs turn employment into an investment decision, generating economic rent and thereby driving a wedge between the highest wage the employer is willing to pay and the lowest wage the employee is willing to accept. The size of this wedge depends on how many employees the firm has "invested" in. Through wage bargaining, the insiders may be able to capture some of the return to this investment. As result of this hold-up problem, firms may have an incentive to employ fewer people than they may otherwise have.

For simplicity, the discussion above has implicitly assumed that workers are either unemployed or employed in the "primary sector" of the labor market, where incumbents all have jobs that are protected by LTCs. In practice, of course, workers generally also have the opportunity of working in the "secondary sector," where labor turnover costs are insignificant and thus the incumbent employees' market power is negligible. Here the marginal incumbent workers in the secondary sector receive remuneration close to their reservation wages. Thus the important divide in terms of worker welfare is not just between the employed and the unemployed, but also between the primary sector insiders (who receive significantly more than their reservation wages) and everyone else. In this "segmented" labor market setting, the equilibrium levels of employment and unemployment depend not only on the LTCs and wages in the primary sector, but also on how the unprivileged workers outside the primary sector choose between unemployment and secondary sector employment. A number of important influences affect this choice. The unprivileged workers are more likely to choose to remain unemployed, (a) the greater are unemployment benefits and associated welfare entitlements, (b) the greater the economic and social stigma from

\footnotetext{
${ }^{32}$ Bertola (1990) arrives at the same qualitative conclusion when the shocks are generated by a twostate Markov chain.

${ }^{33}$ Diaz and Snower (1999) show that the relative magnitude of the direct effect and the indirect wage effect depends on the nature of the business cycle. The more prolonged are macroeconomic fluctuations, the stronger will be the indirect effect relative to the direct effect, and thus the more contractionary will be the influence of labor turnover costs on employment.

${ }^{34}$ For an excellent survey of the implications of the hold-up problem for labor markets, see Malcomson (1997).
} 
secondary-sector employment relative to that from unemployment, ${ }^{35}$ (c) the greater the political power of unions, which often attempt to augment their market power by supporting laws that restrict the size of the secondary sector, (d) the greater the wealth of the unemployed (due to the income effect on labor supply), and (e) the more stratified the society, so that workers who used to be in the primary sector develop a sense of pride that makes it onerous for them to seek work in the secondary sector. ${ }^{36}$

\section{The Dynamics of Employment and Unemployment}

In addition to providing an explanation for the static equilibrium levels of employment and unemployment at any point in time, the insider-outsider theory may also be used to analyze employment and unemployment dynamics. In some contributions to the insider-outsider literature, these dynamics are caricatured as centering on an alleged negative relation between current wages and past employment. Indeed, the insider-outsider theory has often been "tested" by examining the significance of this relationship. However, the dynamic implications of the insider-outsider theory are much more complex and open than this. The alleged relation above is only a special case, which may hold in some cases by not in others. Broadly speaking, the implications cover the behavior of the firms, the insiders, and the outsiders. Let us consider each in turn.

Labor turnover costs have some straightforward implications for the dynamics of firms' behavior. As noted, when hiring and firing is costly, firms' current employment decisions depend positively on their past employment levels. Since insiders and entrants are associated with different turnover costs, the nature of the firm's employment inertia depends on the insider-entrant composition of the firm's workforce. This composition is determined by the firm's "insider membership rule," describing how employees gain and lose insider status within the firm.

Letting $m_{t}$ be the firm's stock of insiders, $n_{t}$ be its total employment, and $\sigma$ be the separation rate, then an example of an insider membership rule is $m_{t}=(1-\sigma) m_{t-1}+$ $a(1-\sigma)\left(n_{t-1}-m_{t-1}\right)$. In words, the current stock of insiders $\left(m_{t}\right)$ is equal to the stock of insiders surviving from the previous period $\left((1-\sigma) m_{t-1}\right)$ plus the number of entrants in

\footnotetext{
${ }^{35}$ For instance McCormick (1990) provides an analysis of economic stigma.

${ }^{36}$ For an analysis of the above mechanisms, see for example Lindbeck and Snower (1990d).
} 
the previous period who become insiders in the current period $\left(a(1-\sigma)\left(n_{t-1}-m_{t-1}\right)\right.$, where $a$ is a constant between zero and one). ${ }^{37}$

Since the firm's current employment $\left(n_{t}\right)$ depends on its stock of insiders $\left(m_{t}\right)$, which in turn depends on its past employment $\left(n_{t-1}\right.$, as well as earlier employment levels, determining $m_{t-1}$ ), the firm's current employment decisions depend on past employment. In this context, the degree of inertia depends on the following string of relations: the relation between past employment and the current insider workforce, between this workforce and the wage, and between the wage and current employment.

On account of this inertia, the employment effects of temporary labor market shocks (e.g., productivity shocks) last longer than the shocks themselves: the "employment persistence" phenomenon. Provided that the labor force response to the shocks is weaker than the employment response, the positive relation between current employment and past employment translates into a positive relation between current unemployment and past unemployment. Thus employment persistence translates into unemployment persistence, i.e., temporary shocks have persistent effects on unemployment.

Fig. 1 provides a simple illustration of such persistence when it is symmetric, i.e., temporary positive and negative shocks of equal magnitude take equally long to die down. In the figure, the unemployment dynamics $(U D)$ curve relates current to past unemployment. An adverse productivity shock shifts the curve upwards, from $U D_{1}$ to $U D_{2}$. As result, unemployment rises from $U_{1}$ to $U_{2}$ in the short run. If the shock is temporary, so that the unemployment dynamics curve shifts back to $U D_{1}$ in the following period, it will take many periods before unemployment returns to its original equilibrium. The greater the slope of unemployment dynamics curve, the greater the degree of unemployment persistence.

In the special case where the slope of the curve is unity, unemployment exhibits hysteresis, as illustrated in Fig. 2. Here a temporary adverse productivity shock leads to a permanent rise in unemployment. However, given that

\footnotetext{
${ }^{37}$ If $n_{t-1}-m_{t-1}<0$, then insiders were fired in the previous period, and thus $a(1-\sigma)\left(n_{t}-m_{t}\right)$ must be subtracted from the previous stock of insiders. This insider membership rule is analogous to a capital accumulation equation in which the current capital stock is equal to the capital stock surviving from the previous period plus the amount of investment. The analogy is worth taking seriously, for labor turnover costs turn labor into a quasi-fixed factor of production, like capital (see Oi (1962)).
} 
unemployment persistence depends on a string of dynamic labor market relations, such as those above, it is clear that the special case of hysteresis can occur only by accident in practice.

Whereas the considerations above are concerned with symmetric persistence, there are good reasons to believe that unemployment persistence is often asymmetric across positive and negative shocks. For instance, insiders who are fired tend to lose their insider status immediately (i.e., $a=1$ when $n_{t-1}-m_{t-1}<0$ ) but entrants generally do not gain insider status correspondingly fast (i.e., $a<1$ when $n_{t-1}-m_{t-1}>0$ ). As result, a past rise in unemployment may have a more powerful effect on future unemployment than does a past employment fall of equal magnitude.

Fig. 3 gives a simple example of this form of persistence. Here the unemployment dynamics curve is kinked at the status quo point ( $U_{0}$ in the figure), indicating greater unemployment persistence in the upward than the downward direction. As shown, a temporary adverse shock shifts the curve upwards from $U D$ to $U D^{\prime}$, so that unemployment initially rises from $U_{0}$ to $U^{\prime}$; whereas an equal and opposite favorable shock shifts the curve downward from $U D$ to $U D^{\prime \prime}$, so that unemployment initially falls from $U_{0}$ to $U^{\prime \prime}$. Observe that it takes longer for the adverse shock to die down than for the favorable shock to do so.

The dynamic behavior of insiders can manifest itself in the wage negotiation process. Blanchard and Summers (1986) and Gottfries and Horn (1987) argue that a negative, mean-reverting productivity shock leads firms to fire some of their insiders, and thereby raises the expected job security of the remaining insiders (since the shock is expected to reverse itself). In response, insiders raise their wages and consequently discourage future employment. Once again, the result is employment persistence (for Gottfries and Horn (1987)) or hysteresis (for Blanchard and Summers (1986)).

This argument is frequently combined with another, namely, that in the presence of diminishing returns to labor, the insider wage may depend inversely on the size of the insider workforce. ${ }^{38}$ Specifically, consider a temporary, negative productivity shock, which leads to a current contraction of the insider workforce. Once the shock has disappeared, the smaller workforce is associated with a higher marginal product of

\footnotetext{
${ }^{38}$ See, for instance, Lindbeck and Snower (1987a).
} 
labor than heretofore (on account of diminishing returns to labor) and thus the insiders will achieve a higher negotiated wage, and thereby discourage future employment.

Although this source of symmetric employment persistence has received much attention in the literature, there are good reasons to believe that it is just a special case. In practice, productivity shocks are generally not mean-reverting. Diminishing returns to labor are at best a short-run phenomenon and, in the presence of excess capital capacity, may well be irrelevant to wage determination. The reason is that when there is excess capital capacity, firms generally vary labor and capital services simultaneously in response to shocks, rather than varying labor relative to a fixed stock of capital in use (see Lindbeck and Snower (1994)).

Observe that the employment persistence above, generated through the dynamics of wage formation, depends critically on the insider membership rule. If, as noted, it takes longer for workers to become insiders after they are hired than it takes them to lose insider status once they are fired, the resulting employment persistence will be asymmetric, viz., negative shocks will be more persistent than positive ones.

Asymmetric movements in employment probabilities over the business cycle can also generate asymmetric persistence. Specifically, in a foreseen upswing, insiders generally face little employment risk, whereas in a downswing their employment risk depends on the size of the downswing. On account of this asymmetric employment risk, insiders may have an incentive to raise their wages more in an upswing than they lower them in a downswing of equal magnitude. The resulting asymmetry in wage setting leads to asymmetric employment persistence. ${ }^{39}$

Finally, dynamic behavior of insiders in response to macroeconomic fluctuations will depend on their preferences. One possibility is that a majority of insiders want to keep the jobs of all insiders in a business downturn and that they therefore accept an overall reduction in their own real wages. This is particularly likely if there is no seniority ranking among them. When there is an unambiguous seniority ranking, the senior workers may instead insist on unchanged wages and let junior workers be laid off. If junior workers try to keep their jobs by underbidding the existing wages, the senior workers may prevent this by threats of non-cooperation and

\footnotetext{
39 See Lindbeck and Snower (1988c). Gottfries and Horn (1987) have an analogous argument with regard to unforeseen shocks.
} 
harassment. Under imperfectly defined seniority rankings, some intermediate strategy may be chosen.

What will happen in a subsequent business upswing is also influenced by insiders' preferences. One extreme case is that the remaining insiders choose to exploit the situation to their own advantage by pushing up wages rather than facilitating increased employment at existing wages. This is the basic idea underlying the hysteresis analysis of Blanchard and Summers (1996) and Gottfries and Horn (1997). The other extreme alternative is that the remaining insiders are anxious to let earlier laid-off workers return and therefore do not push for wage increases in the upswing. This is perhaps particularly likely in small communities where "everybody knows everybody else."

In any case, the insiders' dynamic responses to shocks is likely to generate asymmetric persistence. Arguably, the insiders' disutility from harassing their colleagues, or from refusing to cooperate with them, depends on whether these colleagues are attempting to underbid the insider wages. Such underbidding on the part of junior employees is more likely when employment falls (in a downswing, when the junior employees are in particular danger of dismissal) than when it rises (in an upswing). Thus the insider are more likely to harass and refuse to cooperate in a downswing than an upswing. Consequently, wages may fall less in a downswing than they rise in an upswing of equal magnitude. ${ }^{40}$ Related issues have been discussed in the labor union literature, discussed below. ${ }^{41}$

The above accounts of unemployment persistence rest on the behavior of firms and their insiders. But the insider-outsider theory is equally concerned with the behavior of outsiders. Although the role of insiders has received the lion's share of attention in the insider-outsider literature, it is important to keep in mind that we are dealing with the "insider-outsider" theory, not an "insider" theory. As frequently discussed in the literature, one reason why the dynamic behavior of outsiders may be important is that they often differ from the insiders in their incentives and ability to acquire skills. Workers' skills generally improve through employment and deteriorate through unemployment. Furthermore, firms often exercise some bargaining power in wage negotiations, so that they are able to capture some of the economic rent

\footnotetext{
${ }^{40}$ See Lindbeck and Snower (1988a).
} 
generated by workers' skills. Then firms get more rent from skilled than unskilled workers. Thus when unemployed workers lose their skills, the firms bear some of the resulting cost. The greater is the unemployment rate (particularly, the long-term unemployment rate), the lower will be the rate of skill acquisition (ceteris paribus). Since firms bear some of the resulting cost, the lower will be their demand for the unskilled outsiders. In this way, current unemployment gives rise to future unemployment.

Furthermore, unemployment persistence can also arise when unemployed (particularly long-term unemployed) workers are stigmatized by firms. ${ }^{42}$ Such stigmatization arises when firms use the length of workers' unemployment spells as a predictor of their potential productivity, and this practice is generated by another type of LTC, namely, expected insider-entrant productivity differentials depending on unemployment durations. If, as above, firms capture some of the rent generated by skills, then the longer a worker has been unemployed, the lower is the expected rent associated with that worker and the lower will be his chances of finding a job. In this way, once again, current unemployment comes to depend positively on past unemployment.

Finally, unemployment persistence may arise when outsiders' effort into job search falls with their duration of unemployment. The reason is that their subjective probabilities of finding jobs become smaller, the longer they are unemployed. ${ }^{43}$ If firms capture some of the rent from worker search and skills, then the lower will be the person's actual employment probability. ${ }^{44}$ Since the outsiders thus face progressively larger obstacles to finding jobs the longer they are unemployed, the short-term unemployed compete more effectively for jobs and thus exert more downward pressure on real wages than do the long-term unemployed. Consequently, a current fall in employment (associated with a current increase in unemployment) leads to a future fall in employment. This persistence is generated both directly via firms' employment probabilities and indirectly via the wage determination process.

\footnotetext{
${ }^{41}$ See Carruth and Oswald (1987) and Lockwood and Manning (1989).

42 See, for example, McCormick (1990) and Blanchard and Diamond (1994).

${ }^{43}$ See Layard and Bean (1989).

44 In addition the person's subjective probability may be rational if, for example, the firms use unemployment duration as a screening device for productivity.
} 
Since the outsiders' deterioration of human capital, stigmatization, and depressed job search become more pronounced as the duration of unemployment lengthens, the unemployed outsiders become less effective at competing for jobs with the passage of time. These considerations help explain why real wages and inflation tend to be more responsive to changes in short-term unemployment than to changes in long-term unemployment.

When the outsiders' employment probabilities respond asymmetrically to business fluctuations (viz., these probabilities are positively related to the magnitude of the upturns, but are generally zero in downturns), the resulting employment persistence may again be asymmetric. ${ }^{45}$

These sources of labor market dynamics all imply that the influence of labor market shocks on employment and unemployment is mediated through a network of lagged adjustment processes. $^{46}$ For instance, a change in job security legislation, affecting firing costs, will in general affect the behavior of firms, insiders, and outsiders, and thereby influence not only the employment adjustment process above, but also the outsider search process, the insider membership process, and so on. Thus the LTCs underlying the insider-outsider theory should be viewed as generating, not any particular lagged adjustment process in isolation, but a complex system of interacting adjustment processes.

Moreover, these processes are often complementary. For instance, when there is a temporary, adverse labor demand shock, the employment adjustment process implies that employment will remain low for some time after the shock has disappeared. But because employment remains low, some of the people who lost their jobs become long-term unemployed, and if these people are less effective at competing from jobs than the short-term unemployed, wages will be higher than they would otherwise have been. Consequently, employment remains low for even longer. When adjustment processes are complementary along such lines, ${ }^{47}$ the joint

\footnotetext{
${ }^{45}$ Asymmetries may also arise through the aggregation process. See, for example, Caballero and Engel (1999).

${ }^{46}$ The phenomena above are of course not the only lagged adjustment processes generated through labor turnover costs. For example, costs of moving from temporary to permanent employment, from unskilled to skilled jobs, from junior to senior jobs, etc. may give rise to adjustment process of their own. Moreover, labor turnover costs are, needless to say, not the only sources of lagged adjustment in the labor market. There are many others, such as wage-price staggering and menu costs.

${ }^{47}$ See Karanassou and Snower (1998) for an empirical assessment of such complementarities.
} 
influence of the network of adjustment processes is greater than the sum of the individual processes, and thus it may take unemployment a long time to approach its long-run equilibrium in the aftermath of a shock. ${ }^{48}$ The movement of unemployment through time is then the outcome of the interplay between different adjustment processes. $^{49}$

Thus, in analyzing the movement of unemployment, the insider-outsider theory shifts the focus of attention away from exclusive consideration of changes in the long-run unemployment equilibrium, and emphasizes the significance of adjustment dynamics. These adjustment dynamics have two important functions, particularly in many European countries. First, the longer-term swings in European unemployment may be attributable not just to movements in the natural rate of unemployment (NRU), but also to prolonged deviations of actual unemployment from the NRU. ${ }^{50}$ Second, when the labor market is growing - so that the labor demand and supply curves are moving steadily outwards, on account of technological progress, capital accumulation, and population growth - labor market adjustment processes may prevent the unemployment rate from converging to the NRU in the long run. In empirical studies, the NRU is commonly defined as the rate at which the unemployment rate is constant, given the values of the exogenous variables, i.e., it is the rate of unemployment that would occur if the lagged labor market adjustment processes had been completed. But when the labor demand and labor supply curves are continually shifting outwards, these adjustment processes never have a chance to work themselves out fully. Under these circumstances, the adjustment processes determine how far employment and the labor force are lagging behind their moving targets, and thus determine the difference between the static equilibrium described by the NRU and the dynamic equilibrium to which unemployment rate converges in the long run. ${ }^{51}$

\footnotetext{
48 In general, the influence of these complementarities cannot be captured in a single-equation unemployment autoregression; rather, it is necessary to estimate a labor market system, containing labor demand, wage setting, and labor supply equations.

${ }^{49}$ This interplay is formalized in Karanassou and Snower (1999).

${ }^{50}$ The empirical analysis of Henry, Karanassou and Snower (1999) suggests that the movements of UK unemployment over the past 30 years are due largely to slow adjustment dynamics.

${ }^{51}$ For a formal analysis, see Karanassou and Snower $(1997,1998)$.
} 


\section{Institutions}

The insider-outsider theory also has significant implications for various labor market institutions. In this section we consider two: labor unions and social norms.

\section{Unions}

In much of the traditional literature of union behavior, the existence of unions is taken for granted, rather than explained. ${ }^{52}$ Furthermore, the market power of unions is assumed rather than derived from first principles. ${ }^{53}$ The union is commonly viewed as maximizing utility that depends positively on the wage $(w)$ and employment $(N)$ : $U$ $=U(w, N)$, where $U_{w}, U_{N}>0$. In a particularly popular version of the public interest approach, ${ }^{54}$ it is assumed that union members are alike and chosen at random to fill the available jobs. Thus, letting $M$ be the union's membership, each member faces the probability $=\max (N / M, 1)$ of being employed and achieving utility $U(w)-d$ (where $d$ is the disutility of work), and faces the probability $(1-$ ) of being unemployed and achieving utility $U(b)$ (where $b$ stands for the benefits from being unemployed). The union is assumed to maximize the sum of its members' utilities $(V=N(U(w)-d)+(M-N) U(b))$ or the expected utility of a representative member $(V / M)$. The union's bargaining power is commonly specified in various alternative ways, such as the "monopoly union" model ${ }^{55}$ or bargaining models in which the unions and the employers have bilateral monopoly power. ${ }^{56}$

\footnotetext{
52 There are many surveys of the traditional union literature, e.g. McDonald and Solow (1981) and Oswald (1985).

${ }^{53}$ There are two broad approaches to union behavior. In what may be termed the "public interest" approach, unions are assumed to maximize the welfare of their members. (Often these members are assumed to be homogeneous, permitting a straightforward relationship between the union's welfare function and that of its members.) In what may be called the "public choice" approach (e.g. Roberts (1989)), union decisions are seen as the outcome of voting. (The median voter theory was a wellknown example.)

${ }^{54}$ See, for example, McDonald and Solow (1981).

55 Here the union is assumed to be a monopolist, unilaterally choosing its most preferred wageemployment combination from the labor demand curve it faces.

${ }^{56}$ In these models the relative bargaining strengths of the unions and employers determine how the available rents are split. In the "right-to-manage" model, the union and the employers bargain over the wage (taking the employment implications into account), while the employers determine employment unilaterally (taking the wage as given). In the "efficient bargain" model, the union and the employers bargain over wages and employment simultaneously, exploiting all available gains from trade.
} 
This analysis needs to be modified when the insider-outsider distinction is applied to unionized versus non-unionized workers. First, the insider-outsider theory provides an explanation of what gives unions their clout: labor turnover costs. Firms are reluctant to replace their high-wage unionized employees by low-wage nonunionized ones because it is costly to do so. Unions may arise to further the interests of the insiders, because unions are able to augment and even create labor turnover costs associated with their members and thereby increase their members' market power. In particular, unions augment their members' turnover costs by coordinating their activities: firms are more likely to grant wage increases when the alternative is the replacement of all their unionized employees than when the alternative is just firing a single employee. Unions also provide new tools of rent seeking, such as strikes and work-to-rule activities, which tend to be effective only when workers act in unison. And finally, as noted, unions also commonly act as interest groups in the political process, lobbying for job security legislation and other sources of labor turnover costs.

In providing a rationale for the existence of labor unions, the insider-outsider theory also suggests under what conditions unions tend to thrive. Unions are likely to arise when individual employees' turnover costs are high (so that there is a significant payoff from coordinating their rent-seeking activities), firms have significant market power in product markets (creating rents that may be shared with their employees), the political process is susceptible to job-protection lobbying, and when the existing employment legislation protects rights to strike, picket, and other union rent-creating activities.

Second, the insider-outsider theory highlights that union preferences generally reflect the interests of union members more than those of non-members). For the extreme case in which the union cares only about its members, the objective function of the utilitarian union would be $\hat{V}=M(U(w)-d)$ $+\max (0, M-N)(U(b)-U(w)+d)$. In short, the union's indifference curves have a kink: they are downward-sloping (in real wage-employment space) as long as employment is less than union membership, and flat when employment exceeds 
membership. ${ }^{57}$ Thus in a cyclical upturn (when employment often exceeds membership), the union will push for wage increases; but in a downturn (when employment often falls short of membership), the union will accept a combination of wage and employment cuts.

Third, the insider-outsider theory dispenses with the traditional assumption that union members' employment probabilities are the outcome of a random draw. On account of labor turnover costs, the probability that an unemployed person will be hired tends to be significantly less than the probability that an employed person will be retained. As result, the interests of employed union members are substantially different from their unemployed counterparts. ${ }^{58}$ This observation suggests principles for union membership dynamics. When employment falls short of union membership, the unemployed tend to leave the union, reducing union membership; and when employment exceeds membership, the new entrants may join the union (provided that the conditions, specified above, hold). Membership dynamics are important because, as noted, they influence the path of wages and employment over the business cycle.

Fourth, insofar as labor turnover costs rise with job tenure, the insider-outsider theory suggests that wage and employment contracts may depend on job tenure. ${ }^{59}$ Regarding employment, a "weak" seniority rule specifies that a non-unionized outsider is hired only if all unionized insiders are employed. Frank and Malcomson (1994) show that such a rule may replicate an efficient-bargain outcome and lead to employment at the perfectly competitive level. ${ }^{60} \mathrm{~A}$ "strong" employment seniority rule specifies that the insiders' probabilities of retaining their jobs depend positively on their job tenure. ${ }^{61}$ Similarly, regarding wage setting, such a rule makes insider

\footnotetext{
57 See, for example, Carruth and Oswald (1987), Gottfries and Horn (1987), Huizinga and Schiantarelli (1992), McDonald (1989), and Nickell and Wadhwani (1990). Of course, the preference asymmetry need not be as extreme as portrayed in the utilitarian objective function above. The union may well attach some importance to the employment of outsiders, say, if it cares about future membership (e.g. Huizinga and Schiantarelli (1992), Jones and McKenna (1989)).

${ }^{58}$ In practice unions are primarily concerned with the former, since the employed tend to be far more numerous than the unemployed within unions. In many countries it is common for the unemployed eventually to drop out of their unions.

${ }^{59}$ This is another implication of dropping the assumption that union members get jobs through random draw.

${ }^{60}$ This holds when labor demand is sufficiently large relative to membership and union bargaining power is sufficiently small.

${ }^{61}$ For a union in which decisions are determined by majority voting (i.e., by the median voter), the presence of a strong seniority rule may imply that the union's objectives depend only on the wage. The reason is that the median voter generally does not face the risk of dismissal. (See, for example, Layard
} 
wages a rising function of tenure. In the context of the insider-outsider theory, the rate at which retention probabilities and wages rise with job tenure depends on the rate at which labor turnover costs rise with tenure. ${ }^{62}$

Lastly, the insider-outsider theory has important implications for the nature of the union influence on wage determination. Insofar as labor turnover costs are the source of unions' market power and these costs are generally positive but not prohibitive, the theory raises doubts not only about the monopoly union model, ${ }^{63}$ but also the standard union bargaining models in which unions and employers have bilateral monopoly power. Such bilateral monopoly power can arise only if labor turnover costs are so high that the unionized insiders are more profitable than the nonunionized outsiders at any feasible insider wage. In practice, turnover costs are generally not that high, and thus unions must take competition from outsiders into account.

Under these circumstances, wage determination depends on more than the firms' profit functions, the unions' objectives, and the relative bargaining strengths. It is influenced also by additional constraints, e.g., what may be called a "relative profitability constraint" (the insiders' wage must not exceed the outsiders' reservation wage plus the labor turnover costs), and a "credible threat constraint" (the wage must be such that if firms reject the unions' wage proposals, the union members have an incentive to fulfill the unions' threats, e.g., to go on strike). ${ }^{64}$ Furthermore, as noted, insofar as the degree of substitutability between unionized insiders and non-unionized outsiders depends on the size of turnover costs, these costs influence the nature of the bargaining process. These implications of the insider-outsider dichotomy have not as yet penetrated into the mainstream union literature.

(1990), Oswald (1986).) However, this extreme result disappears when seniority rules are vague or not strictly applied e.g. Turnbull (1988), when insiders are uncertain about labor demand (e.g. Farber (1986)), or when the median voter cares about future voting (e.g. Roberts (1989).

${ }^{62}$ Needless to say, however, that rising intertemporal wage profiles are not just (or even primarily) a union phenomenon. As noted in the discussion subsequent to equation (1) above, the insider-outsider theory also provides an explanation for such profiles when workers negotiate individually.

${ }^{63}$ A union can be a monopolist only if labor turnover costs are prohibitive.

${ }^{64}$ For a discussion of these and other constraints, see Lindbeck and Snower (1987b) and (1988a). 


\section{Social Norms}

In the insider-outsider theory the absence of wage underbidding is explained as the outcome of purposeful (rational) economic behavior of all agents concerned; in this respect we follow traditional methodology in economics. But there are other, or complementary, ways of looking at the issue. For sociologists and many other observers of human behavior, it may be more natural to argue that wage underbidding by outsiders, and the acceptance of such lower bids by firms, is simply not socially unacceptable behavior. In other words, there is assumed to exist a social norm against underbidding the wages of incumbent workers.

Though economists until recently have largely neglected social norms ${ }^{65}$, this has for a bng time have been a basic concept in sociology, in particular in Parsons' (1952) tradition. There is also ample evidence that much human behavior is strongly influenced by social norms; see, for instance, Coleman (1990). A "social norm" is a general rule of behavior that is shared by a group of individuals. Social norms imply that a certain type of behavior is required (expected) by others, and that conformity to this requirement is met by approval and deviation by disapproval, hence by external sanctions that are often social rather than economic in nature. While approval contributes to status and pride, disapproval tends to generate stigmatization and shame. Norms differ from "conventions", which simply imply mutual interest in conformity and are upheld without deliberate external sanctions. Only if a norm is "internalized" in the value system of the individual, and hence integrated in the individual's preferences, are external sanctions unnecessary. In this special case the norm is asserted to create self-respect, and deviation a feeling of guilt.

It is rather generally agreed among sociologists that the labor market is a hotbed for social norms, for instance, in the case of the determination of "proper" work effort and "fair" relative wages; see, for instance, Elster, (1989). How is then the insider-outsider theory related to social norms against wage underbidding? We will argue that though the insider-outsider theory does not have to rely on social norms, it is strengthened by such norms.

\footnotetext{
${ }^{65}$ There was, however, a session on social norms in AER, Papers and Proceedings, May 1997. Other attempts to integrate social norms with economics include Akerlof (1980), Lindbeck (1995a, 1995b)) and Lindbeck, Nyberg and Weibull (1999).
} 
The insider-outsiders theory's closest point of contact with social norms is reached in the non-cooperation and harassment version of the theory. Indeed, some scholars have argued that rational economic calculations are not sufficient to generate and maintain the type of behavior postulated in this version of the theory, and that a social norm against wage underbidding is in fact required (Elster, 1989; Akerlof, 1991). George Akerlof (1980), talks about "codes of honor" among workers concerning relative wages, and against wage underbidding.

The argument that the non-cooperation and harassment version of the insideroutsider theory requires a social norm against wage underbidding is based on the assertion that insiders have no economic incentives to implement the announced non-cooperation and harassment activities if some outsiders, in spite of earlier threats, have already got jobs by way of wage underbidding. The reason is that refusal to cooperate with underbidders may reduce the productivity not only of the underbidders but also of the insiders themselves, and that harassment may create disutility for the harassers themselves. On this account, it has been asserted that threats of non-cooperation and harassment by insiders are not time-consistent, and hence that such threats are not credible (Fehr, 1990).

These assertions do not hold water in a multi-period context (Lindbeck and Snower, 1990b). Insiders may very well be willing to pay both an economic and a psychological price today in order to discourage underbidding in the future. The actual implementation of non-cooperation and harassment would then simply be investment in credibility.

Even though the non-cooperation and harassment version of the insideroutsider theory does not require a social norm against wage underbidding, the existence of such a norm would certainly help insiders protect their positions. Thus, the model becomes richer and more powerful if combined with the notion of a social norm against wage underbidding. Such a norm may be particularly effective in constraining behavior when the norm is shared not only among incumbent workers and potential underbidders, but among managers as well. ${ }^{66}$

\footnotetext{
${ }^{66}$ Some questionnaire studies suggest that managers are even more reluctant than outsiders to pursue, or accept, underbidding offers (Bewley, 1995; Agell and Lundborg, 1995 and 1999.
} 
What remains to be understood is then how such a norm could emerge and be sustained. The insider-outsider theory provides a possible explanation. ${ }^{67}$ Since it is in the insiders' personal self-interest to protect themselves against underbidding, they have incentives to serve both as "senders" and as "monitors" of such a norm. Insiders also have powers to enforce sanctions of norm-breakers - inside as well as outside their firms. Moreover, if non-cooperation and harassment threats are occasionally executed, this not only helps make the threats credible as mentioned above; a norm against wage underbidding is also more likely to be established and sustained. Indeed, history provides many illustrations of the execution of strong disapproval, indeed harsh treatment, of underbidders by incumbent workers. Unions may be important in this respect - not only by making non-cooperation and harassment activities more efficient but also by helping establish and monitor social norms against underbidding among workers and managers.

So called "meta-norms" may also contribute to sustain a social norm against wage underbidding: insiders who do not punish underbidders will be punished themselves by other insiders, and insiders who do not punish those who do not punish will also be punished, etc. Moreover, it is likely that at least some insiders feel satisfaction rather than disutility from harassing underbidders, or from refusing to cooperate with them in the production process, or both. More generally, some individuals may actually enjoy punishing rule-breakers - revenge is a well-known aspect of human behavior. ${ }^{68}$

Thus, in the same way as the insider-outsider theory helps explain the emergence of unions, even though the theory itself does not require unions, the theory also helps explain the emergence and sustainability of social norms against wage underbidding without having to rely on such norms.

\footnotetext{
${ }^{67}$ It is worth emphasizing that this is just one of many possible explanations. The notion of "fair wages," like that of "just prices," is an old one. These notions, along with the dislike of competitors who underbid, often have psychological and sociological sources. We are grateful to Will Baumol for noting this point.

${ }^{68}$ Derogative name-calling may be part of the harassment activity whereby underbidders are punished. The frequently used term "scabs" for underbidders (or its equivalent in other languages) is an illustration. This name-calling can also be seen as part of the process by which social norms against wage underbidding are established and sustained: "framing" by the help of suggestive terms is an important element of the creation of social norms. It is also likely that the social sanctions against underbidders, including the name-calling mentioned earlier, contribute to internalize such a social norm.
} 


\section{Empirical Evidence}

Schematically speaking, there are two different ways of judging the empirical relevance of a theory in the social sciences. One is to use it as a conceptual framework, informally judging whether it makes sense to look upon the world in this particular fashion. The other way is systematic confrontation of the assumptions or predictions of the theory with facts, including the pursuit of formal statistical tests.

Along the first line of judging its empirical relevance, the insider-outsider distinction is frequently invoked in discussions of the employment and unemployment experiences of developed countries, in particular the European unemployment experiences (mentioned in the introduction) - by economists, journalists as well as in economic reports by various institutions. But in many cases it is the terminology and conceptual framework of the theory rather than its tools of analysis that have been applied.

There have also been a number of systematic tests of the theory. The most obvious ones are perhaps tests whether real wages are affected by conditions inside individual firms, and not only by conditions outside. "Inside factors" usually considered are the productivity of workers, output prices or profits ${ }^{69}$, hiring and firing costs and the bargaining strength of workers. Obvious "outside" influences are factors affecting the outside options of workers, such as the aggregate unemployment rate, the fraction of long term unemployed, unemployment benefits and other welfare-state benefits, and wages offered by other firms.

While some studies of this type have relied on cross-section regressions of countries over different production sectors (Coe, 1990; Holmlund and Zetterberg 1991), regions such as states in the US (Kendix, 1981) or production sectors within a country (Mulvey, 1997; Doiron, 1994), others studies have exploited micro-data for individual firms (Blanchflower, Oswald and Garrett, 1989; Nickel and Wadhwani, 1990). ${ }^{70}$ Though statistical tests of complex issues like these are always lazardous, it is fair to say that the results of most tests are consistent with the hypothesis that both

\footnotetext{
${ }^{69}$ The idea that profits influence wages is an old one, even though it contradicts much traditional theory; see, for instance, Slichter (1950) and Lester (1952).

${ }^{70}$ For summaries of parts of the empirical literature in this field, see Holmlund (1990) and Lever (1995).
} 
inside and outside factors influence real wages. ${ }^{71}$ When wages are largely set in the interest of insiders, as postulated by the insider-outsider theory, we would also expect that lay-off rates have a negative influence on real wages, since higher lay off threatens the jobs of insiders. A study for the Netherlands by Graafland (1992) is consistent with this prediction.

The implications of different degrees of insiderness and outsiderness of workers for wage formation have also been studied empirically. Regarding the degrees of insiderness Dolado and Bentolila (1993), for instance, have found evidence that an increase in the number of fixed-term employees (workers with weak inside status) boosts the market powers and the real wages of permanent workers, i.e., those with the highest inside status. A natural interpretation is that temporary workers function as an extra buffer for permanent workers (the "true" insiders) when there are employment-reducing shocks.

There is also ample empirical evidence of the importance for wage formation of different degrees of "outsiderness". A large number of studies indicate that the long-term unemployed exert considerably less (downward) pressure on real wages than do the short-term unemployed (Layard and Nickel, 1987; Lever, 1991; OECD, 1993, p. 94; Crafts, 1989). This finding fits naturally with the insider-outsider framework. Moreover, the prediction that (un)employment inertia (persistence) increases with the level of labor turnover costs is also broadly consistent with empirical studies (Holmlund, 1990; Bentolila and Bertola, 1990; Nickell and Layard, 1997, Table 15). This observation also fits well with empirical evidence that countries with high labor turnover costs have lower exit rates from the unemployment pool than other countries (Alogoskoufis, et al. (1995)).

Cross-country regressions have also confronted the issue of whether high labor turnover costs, and the related boost to insider's market powers, tend to raise the average rate of unemployment over the cycle. Nickel and Layard (1997) do not find any systematic relation of this type in aggregate data in their cross-country study, though they report that long-term unemployment is raised while short-term

\footnotetext{
${ }^{71}$ One curious feature of the literature, though, is that some authors (e.g., Doiron, 1997, Mulvey, 1997) have interpreted the fact that outside factors, and not only insider factors, influence real wages as evidence against the insider-outsider theory - as if the theory had been a pure insider theory rather than an insider-outsider theory.
} 
unemployment is reduced. By contrast, Elmeskov, Martin and Scarpetta (1998) do find that the average rate of unemployment is raised by such arrangements.

The insider-outsider theory also predicts that groups of workers who are not protected by labor-turnover costs of various types, i.e., "typical" outsider-workers, are subject to more frequent and longer spells of unemployment than are core groups of workers. While the core workers largely consist of adult males, the former group consists of new entrants to the labor market, young, married women, and perhaps also elderly workers. This prediction certainly consonant with empirical data (OECD, 1998).

Moreover, the insider-outsider theory leads us to expect that the frequency and duration of unemployment spells for typical outsider groups (such as young workers, women and some minorities) will be comparatively high in countries where insiders enjoy relatively high job security and strong market power. The reason, clearly, is that in the presence of high labor turnover costs, the insiders can insulate themselves from macroeconomic fluctuations to a considerable extent leaving typical outsider groups to bear the main burden of negative shocks. We also expect that across countries with about equally high legislated labor turnover costs but different cyclical fluctuations, the unemployment rates of typical outsider groups will differ widely whereas the unemployment rates of the core groups will be more uniform, and relatively low. The reason would be that cross-country variations in labor turnover costs lead to crosscountry variations in insiders' wage claims (in the insiders' own employment interest), but less variations in the wages of typical outsider groups (because these have a smaller influence on their wages). The available empirical evidence is consonant with these predictions; see, for instance, OECD (1998, Fig. 3). ${ }^{72}$

The theory also makes predictions about the wage structure. In particular, wages are predicted to be relatively high in sectors with high labor-turnover costs, strong unions and high profit, for instance, due to poor competition in product markets. While we have not found any empirical studies concerning the direct

\footnotetext{
72 For instance, in 1996 males in the age group 25-54 constituted 25-30 percent of the total total employment rate (employment/working-age population) in developed OECD countries. By contrast young workers (15-24) constituted 411 percent; older workers (55-64) constituted 2-12 percent; and female adults (25-54) 11-23 percent (Elmeskov Martin and Scarpetta, 1999, Figure 3)
} 
influence of labor-turnover costs, the influence of unions and profits on real wages are fairly well established (e.g., Krueger and Summers (1988)). ${ }^{73}$

Some of the theory's predictions about labor-market dynamics have also been tested. For instance, the existence of unemployment persistence (i.e., the persistence of unemployment effects in the aftermath of labor market shocks) has certainly been confirmed in the literature, in particular, in the case of Western Europe. While some of the evidence consist of eye-ball econometrics, formal tests have given the same result, for instance, in autoregressive (VAR) models; see, for instance, Bean (1997). These empirical results are, however, also consistent with a number of other theories of unemployment. The observation that unemployment persistence is higher in most countries in Western Europe than in the United States has a more direct bearing on the predictions of the insider-outsider theory, according to which persistence would increase with higher labor turnover costs. ${ }^{74}$

Other studies of labor-market dynamics refer to the relations between shortturn (cyclical) macroeconomic fluctuations and labor hoarding, hours of work, capital-labor substitution and productivity movements. For instance, in countries with high labor turnover costs, we would expect relatively large labor hoarding during recessions. This seems to be the case in reality; the size of the workforce tends to fluctuate less relative to output in Western Europe than in the United States over the business cycle. The Okun coefficient is also smaller in the former countries (expressing the change in the unemployment rate per percent change in aggregate output). These features help explain why labor productivity is more pro-cyclical in Western Europe than in the United States. Since labor turnover costs are related to variations in the number of workers, we would also expect that hours of work fluctuate more in countries with high labor turnover costs. This prediction is at least consistent with data for West Germany and the United States (Abraham and Hauseman, 1993).

\footnotetext{
${ }^{73}$ These predictions contrast, to some extent, with the prediction of the efficiency wage theory according to which wages tend to be relatively high where problems of work incentives are particularly important, for instance, when it is important that workers are careful with the capital equipment. As there is support for this hypothesis as well, there seem to be empirical support for both theories, which are not contradictory.

${ }^{74}$ Jaeger and Parkinson (1990) reports higher unemployment persistence in Germany than in the United States.
} 
There is also some evidence that wage adjustment is asymmetric, in the sense that real wages rise more readily in upturns than they fall in downturns, as predicted by various dynamic insider-outsider models. For example, Holzer and Montgomery (1990) find that wages adjust asymmetrically with respect to sales growth, according to a survey of U.S. firms in 1980 and 1982. Blanchflower (1991), studying the British Social Attitudes survey, finds that wages rise when workers expect employment at their firms to rise, but wages remain constant when they expect employment to fall. Nickell and Wadhwani (1991) also find evidence of downward wage rigidity for firms surveyed in the U.K. Begg, Lindbeck, Martin, and Snower (1989) find evidence of asymmetric persistence in the U.K., Japan, and (to a lesser extent) Germany.

By contrast, there is little support for a commonly tested, but quite special insider-outsider model, namely that current wages depend inversely on past employment (which is not a core predictions of the insider-outsider theory); see empirical studies by Nickell and Kong (1988), Nickel and Wadhwani (1990), Lever (1995) and Holmlund (1990) ${ }^{75}$. This theory is often combined with the also highly special hypotheses of pure hysteresis (i.e., that the current unemployment rate is the best estimate of the future unemployment rate). Empirical evidence largely contradicts this hypothesis. ${ }^{76}$

Since capital-labor substitution is stimulated by high real wages, high labor turnover costs are expected to boost labor productivity in the long-run perspective, though perhaps at the expense of the employment level. The insider-outsider approach suggests that this may occur even when there are plenty of unemployed workers around, because high labor turnover costs protect the insiders' position. Investment in firm-specific human capital is also expected to be encouraged by high labor turnover costs. These may be two of the reasons (among many, including technological catch up) why Western Europe (until the early 1990s) experienced a higher rate of long run

\footnotetext{
75 Some of the inspiration for these tests seem to be derived from the work of Blanchard and Summers (1986) who derive a negative relation between the wage change and the lagged employment change, and Gottfries and Horn (1997) who derive a negative relationship between the current wage level and previous employment.

${ }^{76}$ The empirical evidence that in many countries the unemployment rate is I(1), i.e., stationary in first differences, over a span of a few decades does not necessarily imply hysteresis in the long run. After all, the combination of hysteresis and random labor market shocks leads to the counterfactual prediction that unemployment hits zero of 100 percent in finite time. It is plausible to conclude that the I(1) property of unemployment implies that long lagged adjustment processes operate in the labor market.
} 
productivity growth than the United States. In this context, it should be noted that labor productivity is defined with reference to actually employed workers rather than to the labor force, or the number of individuals in working age, in the denominator. This is certainly not a self-evident measure of labor productivity when we look at a country as a whole, rather at specific firms or production sectors. The reason is that unemployed or discouraged workers, with their zero productivity, are not included in the statistics. This means that such a measure boosts measured labor productivity in countries where low-productivity workers are kept out of work by high real wages due to legislation or strong market power of insiders or unions.

Some political-economy implications of the insider-outsider dichotomy have also been investigated empirically. Examples are predictions that insiders are able to push though legislation that boosts the costs of firing workers, that facilitate strikes and that extends collective bargaining agreements to firms without organized workers. There is some empirical support for these assertions; see, for instance, Saint Paul (1996). There seems also to be a positive correlation between the strictness of employment protection legislation (EPL) for permanent workers and the so called "excess coverage" of wage contracts, expressing the extent to which union wage agreements are extended to non-union members. One conceivable interpretation is that insiders, who benefit from strict EPL, have been able to insist on legally enforced extension of wage agreements as a protection against wage underbidding (Elmeskov, Martin and Scarpetta, 1999).

\section{Concluding Thoughts}

We conclude by clarifying some potential misunderstandings about the insideroutsider theory, summarizing some policy implications, and identifying some promising areas of future research.

\section{Potential Misunderstandings}

Since the insider-outsider theory has often been misinterpreted in the literature, and confused with other theories, it may be useful to specify what the theory is not.

First, the theory is not just another name for all the standard theories of wage bargaining. It is easy to entertain this misunderstanding, since many contributions to 
the insider-outsider literature ${ }^{77}$ merely assume that insiders have market power and then use conventional models of imperfect competition to describe the wage determination process. But what makes the insider-outsider theory distinctive is that it analyzes the sources of insiders' market power in terms of labor turnover costs. As we have seen, when these costs are significant but not prohibitive, neither the insiders nor their employers have complete market power, but the relation between these two parties is not characterized by bilateral monopoly. Rather the LTCs determine the degree to which the insider-employer bargains are substitutable for the entrantemployer bargains.

Second, the insider-outsider theory is not just about labor unions. Any employee whose position is protected by labor turnover costs is an insider of sorts, regardless of whether he belongs to a union. But as noted above, unions may give extra clout to the market powers of insiders, and the insider-outsider theory also provides an explanation for the existence and behavior of unions.

Third, the insider-outsider theory is not a variant of the efficiency wage theory. The efficiency wage theory rests on the assumption that wage contracts cannot be based on firms' (imperfect, subjective) information about the profitability of their employees; and on this basis it shows how firms use the wage as an incentive device to attract and motivate their employees. The insider-outsider theory, by contrast, rests on the assumption that incumbent workers in their own interest exploit various labor turnover costs, some of which insiders may influence themselves.

Fourth, the theory does not assert that wages are influenced only by firmspecific phenomena ("inside factors"). Although outsiders are disenfranchised from the bargaining over the insider wages, their situation does in general affect insider wages via outsiders' influence on the insiders' retention probability for given insider wages as well as the outside opportunities of insiders. In other words, outsiders have an indirect influence on wage formation, rather than a direct one, as in perfectly competitive labor markets. Thus, to investigate whether wages are in fact influenced only by conditions inside firms is clearly not a proper test of the theory.

Fifth, the theory does not require social norms against the underbidding of wages, but some of the mechanisms emphasized by the theory - the powers of

\footnotetext{
${ }^{77}$ For example, Blanchard and Summers (1986) and Gottfries and Horn (1987).
} 
insiders to discourage underbidders - may be strengthened by such norms. The theory also helps explain the emergence and sustainability of such norms.

Sixth, the theory does not necessarily assert that wages depend negatively on the initial level of employment, or that unemployment persistence is so great that it generates full hysteresis. ${ }^{78}$ These are special cases of the theory which, as we have seen, are often unsupported by the empirical evidence.

And finally, the theory is not just about European labor markets and European unemployment. Although job security legislation tends to be more stringent in most European countries than in the US, and although union density is usually higher and the coverage of union wage agreements is wider, we argue that labor turnover costs are a ubiquitous feature of all labor markets. Thus, while some institutionally generated turnover costs may be more prominent in Europe, experienced incumbent employees enjoy the protection of labor turnover costs in the U.S. as well, though often less so than in many European countries.

\section{Policy Implications}

Although the specific policy implications of the insider-outsider theory are diverse, they have a common thrust: ${ }^{79}$ Insofar as insiders have more favorable opportunities than outsiders, policies that create a more level playing field in the labor market can improve both efficiency and equity. This is so regardless of what form the insider-outsider distinction takes - employed versus unemployed, primary- versus secondary-sector employed, unionized versus non-unionized workers, and so on. Broadly speaking, there are two types of policies that can create a more level playing field between insiders and outsiders: (i) "power-reducing policies" (that mitigate the insiders' market power, and (ii) "enfranchising policies" (that give the outsiders a stronger voice in the wage determination process.

The power-reducing policies range from restrictions on strikes and picketing to relaxing job security legislation (e.g., laws to streamline firing procedures, reduce litigation costs, and reduce severance pay). These policies are usually not Pareto improving since they tend to reduce insiders' welfare. Thus the insiders may resist

\footnotetext{
${ }^{78}$ This version of the theory became popular through the work of Blanchard and Summers (1986).
} 
these policies either through the political process (e.g., union lobbying) or through rent-creating activities at the place of work (e.g., strikes, increased harassment of underbidders). These insider responses will of course limit the effectiveness of the power-reducing policies.

Enfranchising policies often take the form of vocational training programs and job counseling for the unemployed, ${ }^{80}$ profit-sharing schemes (whereby employees receive part of their remuneration as a share of profits), ${ }^{81}$ schemes to convert wage claims into equity shares, ${ }^{82}$ employment vouchers for the long-term unemployed, ${ }^{83}$ policies to reduce barriers to the entry of new firms (e.g., dismantling of government regulation on the creation of new firms, tax reforms that put new firms at less of a disadvantage vis-à-vis established firms, and policies to reduce the occupational, industrial, and geographic coverage of union wage agreements).

Another general policy implication of the insider-outsider theory concerns the magnitude of required policy change. As noted, labor turnover costs discourage firms from hiring and firing, thereby creating a corridor of wages within which employment is not responsive to policy stimuli. Consequently "timid" labor market reform - in which policy parameters are changed by only small amounts - are likely to be ineffective in labor markets with significant LTCs. Then only "bold" reforms can stimulate employment.

\section{Directions for Future Research}

The theoretical and empirical investigation of the insider-outsider phenomenon is still in its infancy. Many promising areas of research remain virtually unexplored.

On a theoretical plane, much remains to be done in analyzing the role of labor turnover costs in generating insider market power. While we know that these costs make insiders and outsiders imperfect substitutes in the wage bargaining process, little is known about how the nature of these costs and the size of the negotiating groups

\footnotetext{
${ }^{79}$ For a more detailed discussion of these policy implications, see Lindbeck and Snower (1988d, ch. 11;1990c).

${ }^{80}$ For example, Layard (1992).

${ }^{81}$ For example, Weitzman (1987).

${ }^{82}$ See Sinn (1998).

${ }^{83}$ For example, Snower (1994).
} 
affects the degree of imperfect substitutability and thereby the structure of wages. Also little is know about how the existence of a secondary sector and the duration of employment and unemployment affects wage outcomes within this bargaining framework.

On an empirical plane, direct tests of the insider-outsider theory await measurement of the relevant labor turnover costs. Although some of these costs (such as severance pay, training costs, costs of strikes and work-to-rule actions, and litigation costs) are often feasible to measure, others (such as cooperation and harassment activities and effort related costs of labor turnover) are much harder to capture. Furthermore, since different LTCs often protect different sets of insider positions, these LTCs are difficult to aggregate. Nevertheless, far more could be done to assess these costs than has been achieved in the literature thus far. Most empirical insider-outsider models make no attempt to measure LTCs and often implicitly assume (without reason) that these costs are prohibitively high, so that the insideremployer bargaining may be portrayed in terms of bilateral monopoly power. Given the centrality of LTCs to the insider-outsider theory, this is a grave omission, and data collection on these costs would be essential.

The insider-outsider theory implies that the magnitude of insider wages (relative to the reservation wage) depends on the magnitude of LTCs. The share of wages relative to the share of profits is predicted to depend on LTCs (ceteris paribus). Moreover, the theory implies that the relative importance of "inside" versus "outside" factors in wage formation depends on the magnitude of labor turnover costs. These basic implications have yet to be tested directly.

Moreover, we need to investigate the degree to which union power depends on LTCs. Specifically, to what degree is the union wage premium relatively high in sectors with relatively high LTCs (controlling for the degree of product market competition, etc.)?

It would be important to examine whether the relative degree of employment persistence, across firms or sectors, depends on the relative magnitude of LTCs. Although some studies of this issue have been conducted on a macroeconomic plane,${ }^{84}$ little has been done on a less aggregative level.

\footnotetext{
${ }^{84}$ For example, Bertola (1990).
} 
The phenomenon of asymmetric persistence of employment and unemployment remains largely unexplored. Recent theoretical and empirical advances in analyzing irreversibilities in investment could be applied to asymmetric responses of labor markets to external shocks. It would be interesting to explore whether the degree of asymmetric wage-employment responses depends on the magnitude of LTCs. Such analysis may shed light on the question why, over the past 25 years, European unemployment has tended to ratchet upwards from one recession to the next while U.S. unemployment has remained essentially trendless.

We need to examine to what degree the intersectoral wage structure depends on labor turnover costs. In particular, to what degree are intersectoral differences in wages of workers across occupational, educational and seniority groups due to differences in pooled LTCs?

As noted, the insider-outsider and efficiency wage theories offer radically different explanations of segmented labor markets. Segmentation is commonly measured in terms of intersectoral differences in wages, job queues, retention rates, and employment variability. Empirical work evaluating the degree to which these features depend on LTCs versus difficulties in monitoring productivity would be potentially important.

We have also seen that the two theories offer different accounts of why individual intertemporal wage scales often continue to rise even after the trajectory of human capital has flattened out or even declined. We need to investigate the degree to which this divergence of wages and productivity depends on wage incentive effects versus LTCs (e.g., severance pay, authority over colleagues) that rise with job tenure.

It would be important to examine the implications of the insider-outsider theory for the Phillips curve. Are real wages and inflation more closely related to short-term unemployment and more weakly related to long-term unemployment in sectors where LTCs are relatively high?

As noted, the insider-outsider theory implies that the effect of LTCs on employment and unemployment depends, among other things, on the rate of productivity growth and the nature of the business cycle. Specifically, the lower the rate of productivity growth and the longer and more uncertain are recessions, the more adverse are the employment effects of LTCs. This implication deserves empirical assessment as well. 
Finally, it would be worthwhile to investigate whether productivity movements tend to be more pro-cyclical in sectors with relatively high labor turnover costs.

\section{References}

Abraham E.G. and Houseman S. (1993), "Does Employment Protection Inhibit Labor Market Flexibility?" Staff Working Papers, Upjohn Institute for Employment Research, Kalamazoo, II.

Agell, J. and Lundborg, P., (1999), "Survey evidence on wage rigidity and unemployment: Sweden in the 1990s", manus, Department of Economics Uppsala University, Sweden.

Akerlof, G. (1980), "A theory of social custom of which unemployment may be one consequence", Quarterly Journal of Economics, 94(4).

Akerlof, G. (1991), "The Insider-Outsider Theory of Employment and Unemployment", Review of Lindbeck, Assar and Snower, D. J., Scandinavian Journal of Economics, 1991, 93, no.3,472-474.

Alogoskoufis, George, Charles Bean, Giuseppe Bertola, Daniel Cohen, Juan Dolado, and Gilles Saint-Paul (1995), Unemployment: Choices for Europe, Monitoring European Integration Series, London: CEPR.

Andersen, T. M. and Hylleberg, S., 1997, "Wage Adjustment and Employment Persistence", mimeo, Department of Economics, University of Aarhus; and Macroeconomics (forthcoming).

Andersen, Torben M., and Henrik Vetter (1994), "Do Turnover Costs Protect Insiders?” Economic Journal, 104, January, 124-130.

Ball, Laurence (1990), "Insiders and outsiders: A Review Essay," Journal of Monetary Economics, 26, 459-469.

Baumol, William, John Panzar, and Robert Willig (1982), Contestable Markets and the Theory of Industry Structure, New , New York: Harcourt Brace Jovanovich.

Bean C.R., (1997), "The role of demand-management policies in reducing unemployment in: D. J. Snower and G. de la Dehosa (eds.) Unemployment Policy: Government Options for the Labour Market, Cambridge: Cambridge University Press. 
Becker, Gary (1962), Human Capital: A Theoretical and Empirical Analysis, with Special Reference to Education, New York: Columbia University Press.

Begg, David (1988), "Hysteresis, Market Forces, and the Role of Policy in a Dynamic Game with Insiders and Outsiders," Oxford Economic Papers, 40, 587-609.

Begg, David, Assar Lindbeck, Chris Martin, and Dennis J. Snower (1989), "Symmetric and Asymmetric Persistence of Labor Market Shocks," Journal of the Japanese and International Economies, 3(4), December, 554-577.

Bentolila, Samuel, and Gilles Saint-Paul (1994), "A Model of Labor Demand with Linear Adjustment Costs," Labour Economics, 1, 303-326.

Bentolila, Samuel, and Giuseppe Bertola (1990), "Firing Costs and Labor Demand: How Bad is Eurosclerosis?" Review of Economic Studies, 57(3), 381-402.

Bertola, Giuseppe (1990), "Job Security, Employment and Wages," European Economic Review, 34, 851-86.

Bertola, Giuseppe (1992), "Labor Turnover Costs and Average Labor Demand," Journal of Labor Economics, 10, 389-411.

Bewley, T., "Why not cut pay", European Economic Review, 42, 459-490.

Blanchard, Olivier, and Peter Diamond (1994), "Ranking, Unemployment Duration, and Wages," Review of Economic Studies, 61, 417-434.

Blanchard, Olivier, and Lawrence Summers (1986), "Hysteresis and the European Unemployment Problem," NBER Macroeconomics Annual, vol. 1, Cambridge, Mass: MIT Press, 15-77.

Blanchflower (1991), "Fear, Unemployment and Pay Flexibility." Economic Journal, 101:406, pp. 483-496.

Blanchflower, D. G., Oswald A. J. and Garrett, M. D., 1989, "Insider Power and Wage Determination”, NBER Working Paper no. 3179.

Caballero, Ricardo and Eduardo Engel (1999), "Explaining Investment Dynamics in U.S. Manufacturing: A Generalized (S,s) Approach,” Econometrica, 67(4), 783-826.

Carruth, A. A. and Andrew J. Oswald. (1987). "On Union Preferences and Labour Market Models: Insiders and Outsiders," Economic Journal, 97, 431-45.

Chen, Yu-Fu, Dennis Snower, and Gylfi Zoega (1999), "Firing Costs: Eurosclerosis versus Eurosuccesses," Discussion Paper, Birkbeck College, London.

Coase, R. (1937), “The Nature of the Firm,” Economica, 4, 386-405. 
Coe D. T., 1990, "Insider-Outsider Influences on Industry Wages", in W. Franz (ed), Hysteresis Effects in Economic Models, Studies in Empirical Economics. Heidelberg: Physica-Verlag.

Coleman, J. S., (1990), Foundations of Social Theory, Cambridge, MA.:Harvard University Press.

Crafts, N. F. R., 1989, "Long-term Unemployment and the Wage equation in Britain, 1925-1939, Economica, 56(222), May 1989, 247-254.

Diaz, Pilar, and Dennis Snower (1999), "Employment, Macroeconomic Fluctuations and Job Security," mimeo.

Doiron, D. J., 1994, "A Test of the Insider-Outsider Hypotshesis in Union Preferences", Economica, 62 no. 247, 281-290.

Dolado, J. J. and Bentolila S., 1993, "Who Are the Insiders? Wage Setting in Spanish Manufacturing Firms", CEPR Discussion Paper no. 754.

Elmeskov, J. Martin J. P. and Scarpetta, S, (1998), "Key Lessons for Labour Market Reform: Evidence from OECD Countrie's Experiences", Swedish Economic Policy Review 5, 3-50.

Elster, J. (1989), "Social Norms and Economics", Journal of Economic Perspectives, Fall, 3(4), 99-117.

Farber, H. (1986), "The Analysis of Union Behavior," in O. Aschenfelter and R. Layard (eds.), Handbook of Labor Economics, vol. 2, 1039-1089, Amsterdam: North Holland.

Fehr, E. (1990), "Cooperation, Harassment and Involuntary Unemployment: Comment", The American Economic Review, vol.80, no.3, 624-636.

Frank, Jeff and James M. Malcomson (1994), "Trade Unions and Seniority Employment Rules," European Economic Review, 38, 1595-1611.

Gollier, Christian (1991), "Wage Differentials, the Insider-Outsider Dilemma, and Entry-Deterrence," Oxford Economic Papers , 43 (3), 391-408.

Gottfries, Nils, and Henrik Horn (1987), "Wage Formation and the Persistence of Unemployment", The Economic Journal, 97, 388, 877-884.

Graafland, J. J. (1991), "On the Causes of Hysteresis in the Long-Term Unemployment in the Netherlands", Oxford Bulletin of Economics and Statistics, 53 (2), May 1991, 155-170. 
Graafland, J. J. (1992), "Insiders and Outsiders in Wage Formation: The Dutch Case", Empirical Economics, 17, no 4, 583-602.

Henry, Brian, Marika Karanassou, and Dennis Snower (1999), "Adjustment Dynamics and the Natural Rate: An Account of UK Unemployment," Oxford Economic Papers, forthcoming.

Hillman, Arye and Heinrich Ursprung, "Political Culture, Political Liberalization, and Economic Decline," Feb., mimeo.

Holmlund, B. (1990), "Unemployment Persistence and Insider-Outsider Forces in Wage Determination", Stockholm: FIEF.

Holmlund, B., and Zetterberg, J. (1991), "Insider Effects in Wage Determination.

Evidence from Five Countries", European Economic Review, 35, no.5, 1009-1024. OECD (1994), The OECD Job Study: Paris: OECD.

Huizinga, F., and F. Schiantarelli (1992), "Dynamics and Asymmetric Adjustment in Insider-Outsider Models," Economic Journal, 102, 1451-1466.

IMF, (1999), World Economic Outlook, Washington DC.

Jaeger, A., and Parkinson, M. (1990), “Testing for Hysteresis in Unemployment. An Unobserved Components Approach", in W. Franz (ed.), Hysteresis Effects in Economic Models, Studies in Empirical Economics, Heidelberg: Physica-Verlag.

Jansson, P. (1995), "Insider-Outsider Forces in Wage and Employment Determination: The case of Sweden”. Empirical Economics, 20(4), 699-716.

Jones, Stephen R. G. and C. J. McKenna (1989): “The Effect of Outsiders on Union Contracts." European Economic Review, 33, 1567-1573.

Karanassou, Marika, and Dennis J. Snower (1997), "Is the Natural Rate a Reference Point?" European Economic Review, 41, 559-569.

Karanassou, Marika, and Dennis J. Snower (1998), "How Labour Market Flexibility Affects Unemployment: Long-term Implications of the Chain Reaction Theory," Economic Journal, 108, May, 1-18.

Karanassou, Marika, and Dennis J. Snower (1999), "The Chain Reaction Theory of Unemployment: How Unemployment Moves in the Medium Run," mimeo.

Kendix, Michael (1991), “The Effects of Unions on Unemployment and Employment Growth over the Busisness Cycle. Testing for Insider-Outsider Effects," Empirica Austrian Economic Papers, 18, 1, 17-31. 
Krueger, Alan, and Lawrence Summers (1988), "Efficiency Wages and the InterIndustry Wage Structure,” Econometrica, 56, 259-294.

Layard, P. R. G., Nickel, S. J. and Jackman, R,, (1991), Unemployment: Macroeconomic Performance and the Labour Market, Oxford: Oxford Univertity Press.

Layard, P.R.G., and Nickel, S.J. (1987), “The labour market”, in Dornbusch, R and Layard, P.R.G. (eds.), The Performance of the British Economy, Oxford: Oxford University Press.

Layard, Richard, and Charles Bean (1989), "Why does Unemployment Persist?" Scandinavian Journal of Economics, 91(2), 371-396.

Lazear, Edward (1981), “Agency, Earnings Profiles, Productivity and Hours Restrictions," American Economic Review, 71, 606-620.

Lester, R. A., (1952), "A Range Theory of Wage Differentials", Industrial and Labor Relations Review, 5, 483-500.

Lever, M.H.C., (1991), "Union wage setting and unemployment in the Netherlands (1965-1987), Applied Economics, 23, no. 10, 1579-85. Lever, M. H. C., 1995, "Insider-Outsider Effects in Wage Formation: An Empirical Survey", Bulletin of Economic Research, 47, no. 4, 257-274.

Lindbeck A., Nyberg, S., and Weibull, J.,(1999) "Social Norms, the Welfare State and Voting", Quarterly Journal of Economics, 114(1), 1-35.

Lindbeck, A., (1995a), "Welfare State Disincentives with Endogenous Habits and Norms", The Scandinavian Journal of Economics, 97, 4, 477-494.

Lindbeck, A., (1995b), "Hazardous Welfare-State Dynamics", American Economic Review, 85, May.

Lindbeck, Assar, and Dennis J. Snower (1984), "Involuntary Unemployment as an Insider-Outsider Dilemma," Seminar Paper No. 309, Institute for International Economic Studies, University of Stockholm, Sweden.

Lindbeck, Assar, and Dennis J. Snower (1986), "Wage Setting, Unemployment, and Insider-Outsider Relations," American Economic Review, 76(2), May, 235-239.

Lindbeck, Assar, and Dennis J. Snower (1987a), "Union Activity, Unemployment Persistence, and Wage-Employment Ratchets," European Economic Review, Feb, 31, 157-167. 
Lindbeck, Assar, and Dennis J. Snower (1987b), "Strike and Lock-Out Threats and Fiscal Policy," Oxford Economic Papers, 39, 760-784.

Lindbeck, Assar, and Dennis J. Snower (1988a), "Cooperation, Harassment, and Involuntary Unemployment: An Insider-Outsider Approach," American Economic Review, 78, pp. 167-189.

Lindbeck, Assar, and Dennis J. Snower (1988b), "Job Security, Work Incentives and Unemployment," Scandinavian Journal of Economics, 90(4), 453-474.

Lindbeck, Assar, and Dennis J. Snower (1988c), "Long-term Unemployment and Macroeconomic Policy," American Economic Review, Papers and Proceedings, 78, May, 38-43.

Lindbeck, Assar, and Dennis J. Snower (1988d), The Insider-Outsider Theory of Employment and Unemployment, Cambridge: Mass.: MIT Press.

Lindbeck, Assar, and Dennis J. Snower (1990a), "Inter-Industry Wage Structure and the power of Incumbent Workers," in Labour Relations and Economic Performance, ed. by Renato Brunetta and Carlo Dell'Aringa, London: The Macmillan Press, 378-390.

Lindbeck, Assar, and Dennis J. Snower (1990b), "Do Cooperation and Harassment Explain Involuntary Unemployment? Reply," American Economic Review, 1990, June, 80(3), 167-188.

Lindbeck, Assar, and Dennis J. Snower (1990c), "Demand- and Supply-Side Policies and Unemployment: Policy Implicationsof the Insider-Outsider Approach," Scandinavian Journal of Economics, 92(2), 279-305.

Lindbeck, Assar, and Dennis J. Snower (1990d), "Segmented Labor Markets and Unemployment," Seminar Paper No. 483, Institute for International Economic Studies, University of Stockholm, November.

Lindbeck, Assar, and Dennis J. Snower (1991), "Interactions between the Efficiency Wage and Insider-Outsider Theories," Economics Letters, 37 (2), October 1991, pages 193-96.

Lindbeck, Assar, and Dennis J. Snower (1994), "How are Product Demand Changes Transmitted to the Labor Market?" Economic Journal, 104 (423), 386-398.

Lockwood, Ben, and Alan Manning (1989), "Dynamic wage-employment bargaining with employment adjustment," Economic Journal, vol. 99, December, 1143-58. 
Malcomson, James M. (1997), "Contracts, Hold-Up, and Labor Markets," Journal of Economic Literature, 35, December, 1916-1957.

Malcomson, James, M. (1998), "Individual Employment Contracts," Discussion Paper No. 9804, Department of Economics, University of Southampton.

Manzini, Paola, and Dennis J. Snower (1998), “On the Foundations of Wage Bargaining,” IZA Discussion Paper, Bonn.

McCormick, Barry (1990), “A Theory of Sginalling During Job Search, Empoyment Efficiency and 'Stigmatized' Jobs," Review of Economic Studies, 57, April, 299313.

McDonald, Ian M. (1989), "The Wage Demands of a Selfish, Plant-Specific Trade Union," Oxford Economic Papers, 41, 506-527.

McDonald, Ian M., and Robert M. Solow (1981), "Wage Bargaining and Employment," American Economic Review, 71, 896-908.

Mulvey, G. C., (1997), "Can Insider-Outsider Theories Explain the Existence of Unemployment? An Econometric Study of Two British Industries", The Manchester School of Economic and Social Studies, 65, 2, 170-191.

Nickel, Stephen J., and Layard, R., (1997), “Labour Market Institutions and Economic Performance", London School of Economics, Centre for Economic Performance, Discussion Paper no. 23.

Nickel Stephen J., (1997), Unemployment and Labor Market Rigidities: Europe versus North America", The Journal of Economic Perspectives, 11 no. 3, Summer, $55-74$.

Nickell, Stephen J., and Wadhwani S., 1990, "Insider Forces and Wage Determination", The Economic Journal, 100, no.401, 496-509.

Nickell, Stephen J., and P. Kong (1992), “An Investigation into the Power of Insiders in Wage Determination," European Economic Review, 36, 1573-1599.

OECD, (1993), The OECD Job Study, Vol. 1 and 2.Paris: OECD.

OECD, (1998), The OECD jobs strategy: Progress Report on implementation of country specific recommendations, Economic Department Working Paper no. 196.

Oswald, Andrew (1985), "The Economic Theory of Trade Unions: An Introductory Survey," Scandinavian Journal of Economics, 87, 160-193. 
Oswald. Andrew (1986), "Unemployment Insurance and Labor Contracts under Asymmetric Information: Theory and Facts," American Economic Review, 76, 365377.

Oswald, Andrew (1999), “The Housing Market and Europe's Unemployment: A NonTechnical Paper," May, mimeo.

Parsons, T., (1952), The Social System, London: Tavistock Publications.

Roberts, Kevin (1989), "The Theory of Union Behavior: Labor Hoarding and Endogneous Hysteresis," Suntory Toyota International Centre for Economics and Related Disciplines, Discussion Paper No TE/89/209.

Saint Paul, G, (1996), "Exploring the Political Economy of Labour Market Institutions", Economic Policy, October, 265-315

Sanfey Peter J.(1993), "On the Interaction between Efficiency Wages and UnionFirm Bargaining Models.” Economics-Letters; 41(3), 1993, pages 319-24.

Sanfey, Peter J. (1995), "Insiders and Outsiders in Union Models," Journal of Economic Surveys, 9(3), 255-84.

Shaked, Avner, and John Sutton (1984), "Involuntary Unemployment as a Perfect Equilibrium in a Bargaining Model," Econometrica, 52:1351-1364.

Slichter, S. H., (1950), "Notes on the Structure of Wages", Review of Economics and Statistics, 32, 80-91.

Snower, Dennis J. (1994), “Converting Unemployment Benefits into Employment Subsidies," American Economic Review, Papers and Proceedings, 84(2), 65-70.

Tullock, G. (1967), “The Welfare Costs of Tariffs, Monopoly, and Theft," Western Economic Journal, 5, 224-232.

Turnbull, P.J. (1988), "Industrial Relations and the Seniority Model of Union Behaviour," Oxford Bulletin of Economics and Statistics, 50, 53-70.

Williamson, O. (1975), Markets and Hierarchies: Analysis and Antitrust Implications, New York: Free Press. 


\section{IZA Discussion Papers}

$\begin{array}{ll}\text { No. } & \text { Author(s) } \\ 517 & \text { E. Tekin } \\ 518 & \begin{array}{l}\text { P. Carneiro } \\ \text { J. J. Heckman }\end{array} \\ 519 & \begin{array}{l}\text { S. Cohen } \\ \text { Z. Eckstein }\end{array} \\ 520 & \text { U. Sunde }\end{array}$

$$
\text { U. Sunde }
$$$$
\text { R. Fahr }
$$

\begin{tabular}{|c|c|}
\hline & $\begin{array}{l}\varnothing . \text { A. Nilsen } \\
\text { K. Vaage }\end{array}$ \\
\hline 523 & $\begin{array}{l}\text { J. Falkinger } \\
\text { V. Grossmann }\end{array}$ \\
\hline 524 & $\begin{array}{l}\text { J. J. Dolado } \\
\text { F. Felgueroso } \\
\text { J. F. Jimeno }\end{array}$ \\
\hline 525 & $\begin{array}{l}\text { J. J. Heckman } \\
\text { C. Heinrich } \\
\text { J. Smith }\end{array}$ \\
\hline 526 & $\begin{array}{l}\text { E. Leuven } \\
\text { H. Oosterbeek }\end{array}$ \\
\hline 527 & J. C. van Ours \\
\hline 528 & $\begin{array}{l}\text { P. Manzini } \\
\text { M. Mariotti }\end{array}$ \\
\hline 529 & $\begin{array}{l}\text { J. M. Orszag } \\
\text { D. Snower }\end{array}$ \\
\hline 530 & $\begin{array}{l}\text { M. Karanassou } \\
\text { D. Snower }\end{array}$ \\
\hline 531 & $\begin{array}{l}\text { M. Karanassou } \\
\text { H. Sala } \\
\text { D. Snower }\end{array}$ \\
\hline 532 & $\begin{array}{l}\text { J. M. Orszag } \\
\text { D. Snower }\end{array}$ \\
\hline 53 & $\begin{array}{l}\text { S. Fölster } \\
\text { R. Gidehag } \\
\text { M. Orszag } \\
\text { D. Snower }\end{array}$ \\
\hline
\end{tabular}

Title

Child Care Subsidies, Wages, and Employment of Single Mothers

The Evidence on Credit Constraints in Post-Secondary Schooling

Labor Mobility of Immigrants: Training,

Experience, Language and Opportunities

Unobserved Bilateral Search on the Labor

Market: A Theory-Based Correction for a

Common Flaw in Empirical Matching Studies

Employment Status, Endogenous Regional

Mobility, and Spatial Dependencies in Labor Markets

Gender Differences in Early Retirement

Behaviour

Workplaces in the Primary Economy and Wage

Pressure in the Secondary Labor Market

Recent Trends in Occupational Segregation by

Gender: A Look Across the Atlantic

The Performance of Performance Standards

6

07/02

A New Approach to Estimate the Wage Returns to Work-Related Training

The Locking-in Effect of Subsidized Jobs

4

Arbitration and Mediation: An Economic

Perspective

Incapacity Benefits and Employment Policy

3

Unemployment Invariance

3

Unemployment in the European Union: A

Dynamic Reappraisal

07/02

From Unemployment Benefits to Unemployment 3 Accounts

Assessing Welfare Accounts

3

07/02
A. Lindbeck

D. Snower 